\title{
Synthesis
}

\section{Revealing the Driving Forces of Mid-Cities Urban Growth Patterns Using Spatial Modeling: a Case Study of Los Ángeles, Chile}

\author{
$\underline{\text { Mauricio I. Aguayo }}^{1}$, Thorsten Wiegand $^{2}, \underline{\text { Gerardo D. Azócar }}^{1}, \underline{\text { Kerstin Wiegand }}^{3}$, and Claudia E. Vega ${ }^{1}$
}

\begin{abstract}
City growth and changes in land-use patterns cause various important social and environmental impacts. To understand the spatial and temporal dynamics of these processes, the factors that drive urban development must be identified and analyzed, especially those factors that can be used to predict future changes and their potential environmental effects. Our objectives were to quantify the relationship between urban growth and its driving forces and to predict the spatial growth pattern based on historical land-use changes for the city of Los Ángeles in central Chile. This involved the analysis of images from 1978, 1992, and 1998 and characterization of the spatial pattern of land-use change; the construction of digital coverage in GIS; the selection of predictive variables through univariate analysis; the construction of logistic regression models using growth vs. nongrowth for 1978-1992 as the dependent variable; and the prediction of the probability of land-use change by applying the regression model to the 1992-1998 period. To investigate the influence of spatial scale, we constructed several sets of models that contained (1) only distance variables, e.g., distance to highways; (2) only scale-dependent density variables, e.g., density of urban area within a 600-m radius; (3) both distance and density variables; and (4) both distance and density variables at several spatial scales. The environmental variables were included in all models. The combination of distance and density variables at several scales is required to appropriately capture the multiscale urban growth process. The best models correctly predict $~ 90 \%$ of the observed land-use changes for 1992-1998. The distance to access roads, densities of the urban road system and urbanized area at various scales, and soil type were the strongest predictors of the growth pattern. Other variables were less important or not significant in explaining the urban growth process. Our approach, which combines spatial modeling tools and GIS, significantly advances the understanding of urban growth patterns, provides an important contribution to urban planning and management, and can be applied widely.
\end{abstract}

Key Words: land-use change; logistic regression; Los Ángeles, Chile; mid-cities; spatially explicit modeling; urban growth patterns

\section{INTRODUCTION}

\section{Urban growth factors}

City growth and changes in land-use patterns have various social and environmental impacts, including the loss of natural spaces, increased vehicular congestion, landscape fragmentation and homogenization, the loss of highly productive agricultural lands, alterations in natural drainage systems, and reduced water quality (Pickett and Cadenasso 1995, Pickett et al. 1997, 2001, Breuste et al. 1998, Bella and Irwin 2002, Berling-Wolff and Wu 2004a, Pauchard et al. 2006). In addition to the many positive effects of urbanization such as economies of scale and accessibility to education and culture, there are also negative externalities such as congestion, pollution, and criminality. As urban areas expand, the advantages of compact cities are progressively lost (Gordon and Richardson 1997). Thus, for example, the positive effect of agglomeration that comes from reducing transport costs is becoming less important (Glaeser 1998). The combination of a larger and more mobile population with city growth has reduced the quality of life for important segments of the population (Marsh 1991, Sabatini 1998). However, because the world population is growing, urbanization will

\footnotetext{
${ }^{1}$ Environmental Sciences Center EULA-Chile, University of Concepcion, ${ }^{2}$ Ecological Modelling Department, UFZ Centre for Environmental Research, ${ }^{3}$ Institute of Ecology, University Jena
} 
unavoidably continue. It is thus important to understand the underlying mechanisms of city growth to mitigate the negative aspects of urbanization.

Although there are many global factors that explain recent evolution in cities, e.g., national and international market growth and economic globalization, local factors contribute to urban development in the form of specific traits. One of these is the population's socioeconomic situation, which encompasses demographic processes, social status, ethnicity, education and income levels, housing availability, and land-use policies (Azócar et al. 2007). In fact, some researchers have explained the development of new residential neighborhoods on rural land, as well as that of industrial and storage areas, through the construction of highways and new access routes (Hylton 1995, Parker 1995). Thus, accessibility is still considered to be one of the factors that best explains the development of urban service, commerce, and industrial activities, as well as residential and recreational projects (Newman et al. 1992, Azócar et al. 2007). Herbert and Thomas (1982) suggested that urban sprawl has commonly been controlled by communication networks and accessibility. Therefore, main access routes constitute important attractors for urban activities and generate different urbanization patterns. Recent studies in two Chilean cities, Chillán and Los Ángeles, showed constant expansion of both cities away from their historic downtowns, but not away from the main access routes (Azócar et al. 2003, 2007, Henríquez et al. 2006).

\section{Mid-cities}

Mid-cities is a new concept in the social sciences and is connected to territorial development policies. At the global level, urban centers having between 20,000 and 2,000,000 inhabitants are considered to be mid-cities; this range varies by cultural, territorial, demographic, and economic context (Bellet Sanfeliu and Llop Torné 2004) and fluctuates between 50,000 and 1,000,000 for Chile and Latin America in general (Rodríguez and Villa 1998, Sabatini 1998). Regardless of the population range considered, these cities play an enormous role globally. Approximately $62 \%$ of the world's urban population resides in cities with less than $1 \times 10^{6}$ inhabitants (Bellet Sanfeliu and Llop Torné 2004).

Although population criteria provide some clarity with regard to these cities, they are incomplete without the concept of intermediation, which gives meaning to the definition of mid-cities. Urban intermediation refers to the city's role in topological structuring, that is, its integration and articulation functions over vast territories. In addition, with respect to scale, mid-cities are characterized by easy management and fewer social conflicts and environmental problems (Bellet Sanfeliu and Llop Torné 2004). Research on the Chilean cities of Valdivia (Borsdorf 2000), Puerto Montt (Rovira Pinto 2000), Temuco (Romero and Toledo 2000), and Los Angeles (Azócar et al. 2003) shows agreement on the importance of mid-cities as centers of regional and provincial administration, provision of services to the hinterlands, and industrial transformation of natural resources. Chilean mid-cities are especially interesting because some have had higher growth rates than the large cities, particularly in the most recent intercensus periods (González 1994, Rodríguez and Villa 1998, Sabatini 1998).

\section{Modeling changes in urban land use}

The study and evaluation of urban growth patterns and the forces driving their transformation require the management and use of spatial analysis, statistics, and GIS techniques. These techniques are necessary for understanding the complex dynamics of these processes and their multiple causal factors (Wu 1998, Pijanowski et al. 2002, Berling-Wolff and $\mathrm{Wu} 2004 b$ ). In fact, these techniques help to identify spatial patterns and predict and/or simulate future changes or tendencies (Qi and Wu 1996, Wu 1998, de Koning et al. 1999, Berling-Wolff and Wu 2004b). Models for land-use change have been developed into a powerful tool for spatial analysis, mostly oriented at (1) exploring the various mechanisms that drive land-use change and the social, economic, and spatial variables leading to change (de Koning et al. 1999); (2) projecting the potential environmental and socioeconomic impacts of changes in land use (Alig 1986, McDonnell and Pickett 1993, Foresman et al. 1997, Theobald et al. 1997); and (3) evaluating the influence of different policies and management regimes on development and land-use patterns (Bockstael et al. 1996).

Models of land-use change rely on simple parameters, including the urban area's present extension, main transport routes, distances to workplaces and goods, topographical conditions, and the existence of land with special conditions, e. 
g., protected areas. The main purpose of modeling is to identify the physical and socioeconomic factors that determine or condition pressure for land-use change at the urban-rural interface (White and Engelen 2000). The two prevalent approaches to modeling spatial land-use change patterns are regression-based models and models based on spatial transition (Theobald and Hobbs 1998, Brown et al. 2002, Pijanowski et al. 2002). In the former approach, a relationship is established between a wide range of predictive variables and the probabilities of land-use change; the latter approach is an extension of Markov's aspatial technique and a form of stochastic cellular automaton (Zhou and Liebhold 1995).

The objective of regression-based models is to establish functional relationships within a set of appropriate spatial variables that are then used to predict the locations of changes in the landscape. The influence of these local factors on land-use change is traditionally modeled using the distance decay function in which the strength of the influence decreases as the distance increases (LaGro and DeGloria 1992, Theobald and Hobbs 1998). The approaches usually taken in regression-based modeling are linear, i.e., logistic regression, nonlinear, i.e., linked to neuronal networks, or generalized and additive (Brown et al. 2002, Pijanowski et al. 2002).

We used logistic regression modeling to quantify the relationship between urban growth in the midcity of Los Ángeles and its causal factors at a fine scale with a resolution of $30 \mathrm{~m}$ and to predict the spatial patterns of this growth. We placed special emphasis on investigating the role of spatial scales by using scale-dependent neighborhood density variables that measured, for example, road density at neighborhoods of various distances from the focal point, and by considering two random growth models operating at scales of 3000 and $500 \mathrm{~m}$ from the city perimeter. A random growth model was required to select areas that did not grow for comparison to the areas with observed growth using logistic regression.

\section{METHODS}

\section{Study area}

The city of Los Ángeles is located in central Chile's Biobío Region (37 $\left.30^{\prime} \mathrm{S}, 72^{\circ} 20^{\prime} \mathrm{W}\right), 500 \mathrm{~km}$ south of the capital city, Santiago. Demographically, with
123,500 inhabitants, it is considered a mid-city. In the most recent intercensus period of 1992-2002, the city's population grew at an annual rate of $2.6 \%$, which was double the population growth rate of Santiago for the same period. Data from population censuses from 1940 to 1992 show growing participation by Los Ángeles in the total township population and even in the total provincial population of Biobío Province. In 1940, 40.1\% of the township's population resided in the city of Los Ángeles; by 1992 this proportion had increased to $67.4 \%$. In other words, a notable process of population concentration has occurred in the city of Los Ángeles in recent decades (Henríquez et al. 2006, Azócar et al. 2007). Agricultural and forestry activities dominate the natural environment of Los Ángeles (Fig. 1), which is situated on deep and welldrained soils, with slopes that do not surpass $5 \%$. In general, Los Ángeles is the main urban center in Biobío Province and is where the principal commercial, financial, and service activities are concentrated.

\section{Spatial database}

A spatial database was generated for 1978, 1992, and 1998 using georeferenced digital aerial photographs. Thematic coverage maps were obtained using photointerpretation techniques and included urban and rural land use; roadway infrastructure; commercial, health, and educational amenities; and financial services. The digital coverage of the water network, contours, and soil types was obtained from official cartographic sources such as base maps from the Military Geographic Institute (Instituto Geográfico Militar) and orthophotos from the Natural Resource Research Center (Centro de Investigación de Recursos Naturales). This digital information was stored and managed in ArcView 3.3 (ESRI, Redlands, California, USA) and IDRISI 14.02 (Clark University, Worcester, Massachusetts, USA) GIS software. All spatial data were transformed to raster formats with $30 \times 30$-m cell sizes.

\section{Changes in urban land use}

Changes in urban land use were quantified by analyzing aerial photographs of the city of Los Ángeles from 1978, 1992, and 1998 (Fig. 2A). For the periods 1978-1992 and 1992-1998, we obtained maps showing cells changing from nonurban to 
Fig. 1. Study area location in Chile and land use classification in 1998.

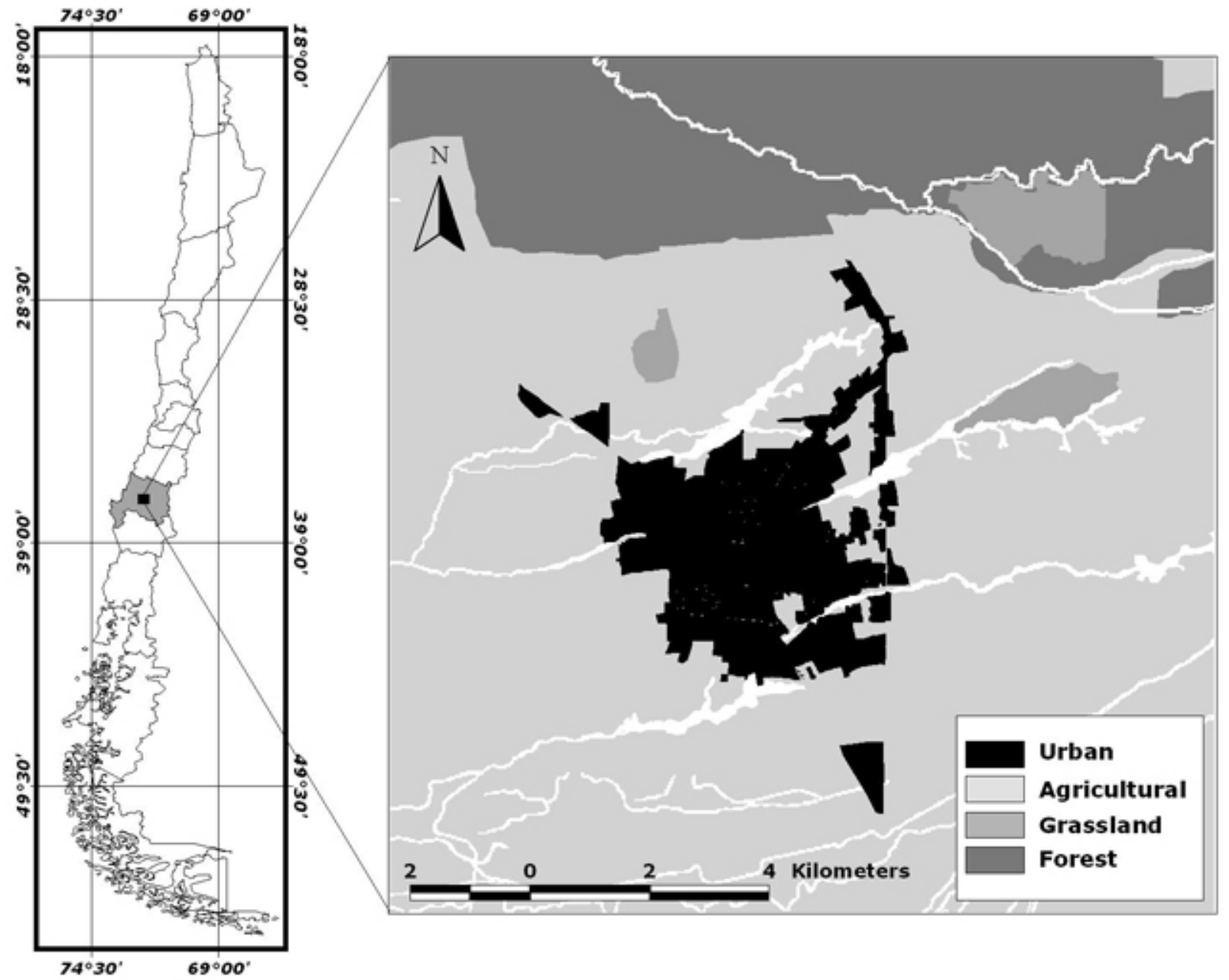

urban and cells remaining nonurban. Transitions from urban to nonurban did not occur, and cells that were already urban were excluded, but were used to derive predictive variables such as distance to the city perimeter. The process of growth and urban change was quantified using transition matrices. The matrix axes represented land-use categories between periods; the matrix cells represented the number of pixels that changed from one category to another; and the matrix diagonal represented pixels that did not undergo any changes during the study period (López et al. 2001).

\section{Variable identification and preparation}

To quantify the relationship between urban growth and its causal factors, we related the map of 19781992 land-use change (Fig. 2B) to a set of predictor variables that was selected a priori using hypothesized environmental relations based on our current knowledge of the urbanization process in Los Ángeles. A priori variable selection is important in model selection to avoid data mining and for the use of only those variables that can be interpreted (Burnham and Anderson 1998, Johnson and Omland 2004). An appropriate binary response 
Fig. 2. (A) Urban area in 1978, 1992, and 1998. (B) Observed spatial growth pattern from 1978 to 1992. (C) Random spatial growth pattern for a growth surface of $3000 \mathrm{~m}$ used to select cells with no growth for the binary response variable of the logistic regression model. The random growth pattern was created by dividing the area with urban growth between 1978 and 1992 into fragments smaller than 150 cells (13.5 ha) and distributing them randomly without overlap within an area < $3000 \mathrm{~m}$ from the 1978 city perimeter, i.e., the potential urban growth surface. (D) Random spatial growth pattern for a growth surface of $500 \mathrm{~m}$. The random growth pattern was created analogously to that in (C) using a maximum distance of $500 \mathrm{~m}$ from the 1978 city perimeter.

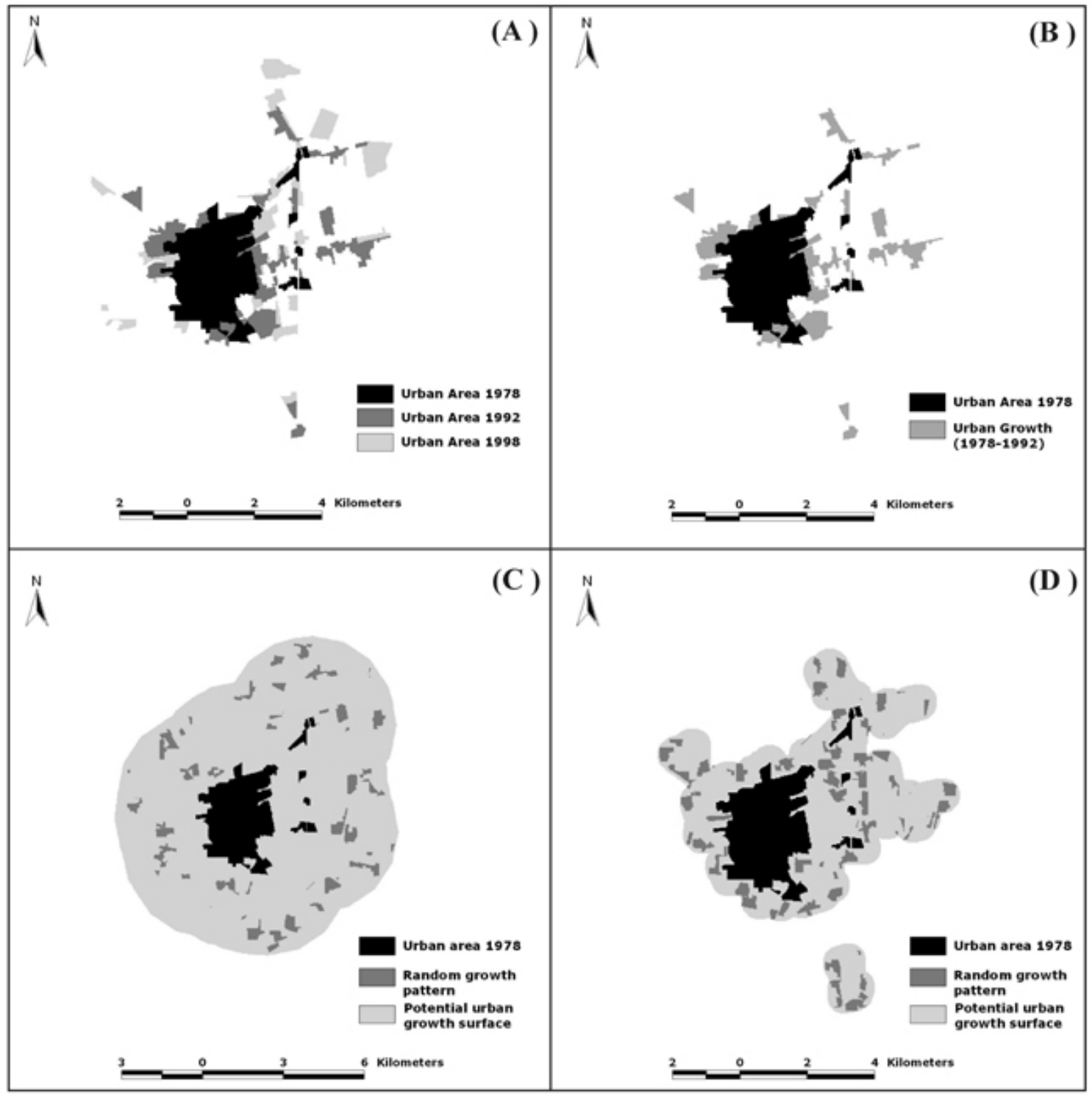


variable was constructed from the observed growth pattern (Fig. 2B), and general linear models (Burnham and Anderson 1998) with binomial distributions for binary response variables, i.e., logistic regression, were used to derive models that predict the probability of urban growth depending on the various predictor variables. The significance of the predictor variables provides information on their importance in determining urban growth processes, and the model can be used to predict the spatial pattern of growth.

Variables hypothesized to act as driving forces of urban growth were selected from prior studies of Los Ángeles and other mid-cities of central Chile (Borsdorf 2000, Romero and Toledo 2000, Rovira Pinto 2000, Azócar et al. 2003) and from the analysis of a temporal series of aerial photographs. These variables were then classified according to their interaction with the observed areas of urban growth as (1) distance variables, indicating distances to certain elements such as roadway infrastructure or the city perimeter; (2) neighborhood variables, indicating the scale-dependent densities of certain elements such as roadway infrastructure within a circular area of specific radius from a focal point); or (3) environmental variables, indicating the presence, absence, or value of environmental factors that may limit or strengthen urban growth (Table 1).

Distances were calculated using a proximity analysis in which each $30 \times 30 \mathrm{~m}$ cell was assigned the minimal distance to a determined element such as cells with access roads, industrial areas, or an existing middle-class neighborhood. In contrast, scale-dependent neighborhood density variables were calculated using a circular moving window algorithm (Schadt et al. 2002, Naves et al. 2003) that assigned the mean value of the variable within a circular area of specific radius to the focal cell. By moving the circle over the entire grid, we obtained a value of the variable for each cell of the grid. The effect of scale on the results was evaluated by considering radii of $150,300,600,900$, and 1200 $\mathrm{m}$; these radii ranged from the immediate neighborhood to about one-half of the city perimeter.

\section{Statistical analysis}

\section{Random growth models}

Logistic regression requires the use of a binary response variable. A value of 1 corresponds to an occurrence of the variable of interest, e.g., change in land use from nonurban to urban (e.g., Fig. 2B, gray area); a value of 0 corresponds to the nonoccurrence of the variable, e.g., no change from nonurban to urban (e.g., Fig. 2B, black area). We constructed the response variable from the observed growth pattern using several steps.

In the first step, we assigned a value of 1 to all $30 \times$ $30 \mathrm{~m}$ cells that had a land-use change from nonurban to urban; all other cells were assigned a value of 0 , corresponding to no change in land use. However, there were many more cells with no growth than with growth, which presented the problem of how to appropriately reduce the number of cells with a value of 0 . There are several possibilities, and the appropriate selection depends on the aim of the model and the characteristics of urban growth. Most urban growth occurred in the neighborhood of areas that were already urbanized, but occasionally an isolated area up to $3000 \mathrm{~m}$ from the city's perimeter was urbanized (Fig. 2A). Therefore, cells that were too far from the city's perimeter were excluded from those with a value of 0 . However, because the maximal distance from the city's perimeter that was accepted to include cells with a value of 0 may critically influence the outcome of the model, we selected two different sets of cells with a value of 0 at distances of 3000 and $500 \mathrm{~m}$ from the city's perimeter, hereafter called the "random growth model."

The selection of the 3000-m distance accepted cells with no growth from a relatively wide area around the city's perimeter, including agricultural, grassland, and forest areas (Fig. 2C). The $3000 \mathrm{~m}$ was the maximum distance of any cell with growth from the city's perimeter during the study period (Henríquez et al. 2006). This selection may allow the identification of coarse factors determining urban growth because it may include environmental conditions with an a priori low likelihood of growth. However, cells in the immediate neighborhood of the city in 1978 had a high probability of diffusion growth (Fig. 2A). To explore more subtle factors discriminating growth and no growth in these areas, we used the second random growth model with the smaller maximal distance of $500 \mathrm{~m}$ from the city's perimeter (Fig. 2D).

To obtain an equilibrated number of cells with values of 0 and 1 , we could randomly select a number of cells with a value of 0 , i.e., as many as the observed number of cells with a value of 1 , from the areas with no growth within the 3000- or 500- 
Table 1. Derived variables considered in the statistical analysis and their mean values in cells with growth and no growth of the independent variable (see Fig. 3B,D).

\begin{tabular}{|c|c|c|c|c|c|c|c|}
\hline Variable & $\begin{array}{c}\text { Abbrevia- } \\
\text { tion }\end{array}$ & $\mathrm{S}_{3000} \dagger$ & $\mathrm{S}_{500} \neq$ & $\begin{array}{l}\text { Mean } \pm \\
\text { SD growth } \\
\mathrm{S}_{3000}\end{array}$ & $\begin{array}{c}\text { Mean } \pm \\
\text { SD no } \\
\text { growth } \mathrm{S}_{3-} \\
000\end{array}$ & $\begin{array}{l}\text { Mean } \pm \\
\text { SD growth } \\
\mathrm{S}_{500}\end{array}$ & $\begin{array}{c}\text { Mean } \pm \\
\text { SD no } \\
\text { growth } \mathrm{S}_{500}\end{array}$ \\
\hline
\end{tabular}

\section{(A) Distance variables, giving distance from:}

\begin{tabular}{|c|c|c|c|c|c|c|c|}
\hline Urban road network & dstcam & $* * \S$ & $* * \S$ & $\begin{array}{r}186.10 \pm \\
190.69\end{array}$ & $\begin{array}{c}463.18 \pm \\
367.21\end{array}$ & $\begin{array}{c}187.96 \pm \\
189.91\end{array}$ & $\begin{array}{r}283.91 \pm \\
179.26\end{array}$ \\
\hline Urban perimeter & dstcdad & $* * \S$ & $* * \S$ & $\begin{array}{c}618.24 \pm \\
650.14\end{array}$ & $\begin{array}{c}1750.60 \\
\pm 653.56\end{array}$ & $\begin{array}{c}668.27 \pm \\
712.51\end{array}$ & $\begin{array}{c}987.69 \pm \\
919.75\end{array}$ \\
\hline City center & dstctro & $* *$ & & $\begin{array}{r}2064.95 \\
\pm 1075.02\end{array}$ & $\begin{array}{c}3616.52 \\
\pm 942.41\end{array}$ & $\begin{array}{c}2130.69 \\
\pm 1131.07\end{array}$ & $\begin{array}{c}2213.59 \pm \\
1130.32\end{array}$ \\
\hline Amenities and services & dsteqp & $* *$ & & $\begin{array}{c}1038.46 \\
\pm 661.54\end{array}$ & $\begin{array}{r}2019.96 \\
\pm 702.52\end{array}$ & $\begin{array}{r}1089.50 \\
\pm 730.06\end{array}$ & $\begin{array}{c}1278.59 \pm \\
952.16\end{array}$ \\
\hline Rivers and estuaries & dstrio & & & $\begin{array}{c}527.40 \pm \\
330.30\end{array}$ & $\begin{array}{r}587.66 \pm \\
475.48\end{array}$ & $\begin{array}{c}514.31 \pm \\
334.78\end{array}$ & $\begin{array}{c}503.15 \pm \\
378.81\end{array}$ \\
\hline Highways & dsttcam2 & $* * \S$ & & $\begin{array}{c}1822.10 \\
\pm 1463.23\end{array}$ & $\begin{array}{c}2346.69 \\
\pm 1656.24\end{array}$ & $\begin{array}{c}1781.42 \\
\pm 1481.91\end{array}$ & $\begin{array}{c}1858.52 \pm \\
1715.29\end{array}$ \\
\hline Access roads & dsttcam3 & $* * \S$ & $* * \S$ & $\begin{array}{c}697.79 \pm \\
745.80\end{array}$ & $\begin{array}{c}1757.97 \\
\pm 1150.80\end{array}$ & $\begin{array}{c}740.68 \pm \\
853.68\end{array}$ & $\begin{array}{c}1067.01 \pm \\
1118.25\end{array}$ \\
\hline Urban roads & dsttcam4 & $* *$ & $* * \S$ & $\begin{array}{r}1115.58 \\
\pm 1137.25\end{array}$ & $\begin{array}{c}2439.46 \\
\pm 1226.03\end{array}$ & $\begin{array}{c}1132.58 \\
\pm 1145.02\end{array}$ & $\begin{array}{c}1437.83 \pm \\
1154.69\end{array}$ \\
\hline Rural roads & dsttcam5 & & & $\begin{array}{c}703.17 \pm \\
504.29\end{array}$ & $\begin{array}{r}675.20 \pm \\
431.02\end{array}$ & $\begin{array}{r}711.44 \pm \\
495.14\end{array}$ & $\begin{array}{c}730.66 \pm \\
533.61\end{array}$ \\
\hline Railroads & dsttcam6 & $* * \S$ & & $\begin{array}{r}2147.59 \\
\pm 1468.42\end{array}$ & $\begin{array}{c}2834.98 \\
\pm 2058.15\end{array}$ & $\begin{array}{c}2200.15 \\
\pm 1460.59\end{array}$ & $\begin{array}{c}2530.94 \pm \\
1557.03\end{array}$ \\
\hline Lower-class neighborhoods & dsttcdad1 & $* *$ & $* *$ & $\begin{array}{r}1155.64 \\
\pm 1072.99\end{array}$ & $\begin{array}{c}2538.05 \\
\pm 1000.03\end{array}$ & $\begin{array}{r}1211.59 \\
\pm 1093.77\end{array}$ & $\begin{array}{c}1571.19 \pm \\
1132.19\end{array}$ \\
\hline Middle-class neighborhoods & dsttcdad2 & $* *$ & $* *$ & $\begin{array}{c}1533.30 \\
\pm 1032.63\end{array}$ & $\begin{array}{c}2966.30 \\
\pm 1054.04\end{array}$ & $\begin{array}{c}1592.29 \\
\pm 1072.05\end{array}$ & $\begin{array}{c}1971.42 \pm \\
1214.91\end{array}$ \\
\hline Upper middle-class neighborhoods & dsttcdad3 & $* *$ & $* *$ & $\begin{array}{r}1870.33 \\
\pm 1219.67\end{array}$ & $\begin{array}{c}3492.79 \\
+1122.31\end{array}$ & $\begin{array}{c}1921.24 \\
\pm 1268.27\end{array}$ & $\begin{array}{c}2550.08 \pm \\
1239.95\end{array}$ \\
\hline Industrial areas & dsttcdad4 & $* *$ & & $\begin{array}{c}920.12 \pm \\
687.68\end{array}$ & $\begin{array}{r}1916.29 \\
\pm 706.11\end{array}$ & $\begin{array}{c}962.12 \pm \\
761.21\end{array}$ & $\begin{array}{c}1224.26 \pm \\
1045.47\end{array}$ \\
\hline
\end{tabular}

\section{(B) Neighborhood variables, giving density of:}

Urban road network at $150 \mathrm{~m} \quad$ dncam05 $\quad * * \S \quad * * \S \quad 7.20 \pm 7.43 \quad 2.93 \pm 5.797 .22 \pm 7.63 \quad 3.07 \pm 5.74$ 
Urban road network at $300 \mathrm{~m}$

Urban road network at $600 \mathrm{~m}$

Urban road network at $900 \mathrm{~m}$

Urban road network at $1200 \mathrm{~m}$

Urban area at $150 \mathrm{~m}$

Urban area at $300 \mathrm{~m}$

Urban area at $600 \mathrm{~m}$

Urban area at $900 \mathrm{~m}$

Urban area at $1200 \mathrm{~m}$

Amenities and services at $150 \mathrm{~m}$

Amenities and services at $300 \mathrm{~m}$

Amenities and services at $600 \mathrm{~m}$

Amenities and services at $900 \mathrm{~m}$

Amenities and services at $1200 \mathrm{~m}$

Lower-class neighborhoods at $150 \mathrm{~m}$

Lower-class neighborhoods at $300 \mathrm{~m}$

Lower-class neighborhoods at $600 \mathrm{~m}$

Lower-class neighborhoods at $900 \mathrm{~m}$

Lower-class neighborhoods at $1200 \mathrm{~m}$

Middle-class neighborhoods at $150 \mathrm{~m}$

Middle-class neighborhoods at $300 \mathrm{~m}$

Middle-class neighborhoods at $600 \mathrm{~m}$

Middle-class neighborhoods at $900 \mathrm{~m}$

Middle-class neighborhoods at $1200 \mathrm{~m}$

Upper middle-class neighborhoods at 150 dntcdad305 $\mathrm{m}$

Upper middle-class neighborhoods at 300 dntcdad310 $\mathrm{m}$

$\begin{array}{lll}\text { dncam10 } & * * \S & * * \\ \text { dncam20 } & * * \S & * * \\ \text { dncam30 } & * * \S & * * \\ \text { dncam40 } & * * \S & * * \\ \text { dncdad05 } & * * \S & * * \\ \text { dncdad10 } & * * \S & * * \\ \text { dncdad20 } & * * \S & * * \\ \text { dncdad30 } & * * & * * \\ \text { dncdad40 } & * * & * *\end{array}$

dneqp05

dneqp 10

dneqp20

dneqp30

dneqp40

dntcdad 105

dntcdad110 ***

dntcdad120

dntcdad 130

dntcdad140

dntcdad205

dntcdad210

$\operatorname{dntcdad} 220$

dntcdad230

$* * \S$

$* *$

$* * \S$
$6.61 \pm 4.44 \quad 2.83 \pm 3.66 \quad 6.54 \pm 4.57 \quad 3.65 \pm 4.04$

$5.73 \pm 3.01 \quad 2.66 \pm 2.34 \quad 5.72 \pm 3.08 \quad 4.61 \pm 2.35$

$5.73 \pm 2.28 \quad 2.80 \pm 1.79 \quad 5.69 \pm 2.37 \quad 4.80 \pm 1.77$

$5.81 \pm 2.182 .99 \pm 1.45 \quad 5.76 \pm 2.23 \quad 4.65 \pm 1.60$ $\begin{array}{ccc}6.38 \pm 14- & 0 & 5.99 \pm 14- \\ .68 & 0.42 \pm 2.53\end{array}$

$9.57 \pm 16-0.02 \pm 0.299 .08 \pm 16-1.98 \pm 5.65$ .58

$13.23 \pm 1-0.29 \pm 1.9712 .74 \pm 1-6.29 \pm 9.92$ 6.81 7.09

$15.36 \pm 1-0.79 \pm 3.5414 .92 \pm 1-8.39 \pm 11.25$ $6.01 \quad 6.31$

$16.97 \pm 1-1.47 \pm 4.6416 .51 \pm 1-9.15 \pm 11.45$ 5.47

5.81

$0.03 \pm 0.18 \quad 0 \quad 0.03 \pm 0.19 \quad 0$

$0.03 \pm 0.10 \quad 0 \quad 0.04 \pm 0.11 \quad 0.01 \pm 0.05$

$0.03 \pm 0.06 \quad 0.00 \pm 0.01 \quad 0.03 \pm 0.06 \quad 0.03 \pm 0.05$

$0.05 \pm 0.07 \quad 0.00 \pm 0.02 \quad 0.05 \pm 0.08 \quad 0.04 \pm 0.05$

$0.07 \pm 0.10 \quad 0.01 \pm 0.02 \quad 0.07 \pm 0.10 \quad 0.04 \pm 0.06$

$3.04 \pm 9.91 \quad 0 \quad 2.50 \pm 8.740 .18 \pm 1.89$

$4.94 \pm 11-0.02 \pm 0.29 \quad 4.29 \pm 9.93 \quad 0.77 \pm 4.59$ .19

$7.33 \pm 11-0.20 \pm 1.576 .88 \pm 10-2.48 \pm 7.07$ .01

.68

$7.97 \pm 9.54 \quad 0.39 \pm 2.09 \quad 7.56 \pm 9.48 \quad 3.55 \pm 6.69$

$7.61 \pm 8.04 \quad 0.67 \pm 2.51 \quad 7.22 \pm 7.96 \quad 4.12 \pm 6.26$

$1.22 \pm 7.67 \quad 0 \quad 1.30 \pm 8.08 \quad 0.02 \pm 0.24$

$1.40 \pm 7.82 \quad 0 \quad 1.49 \pm 8.52 \quad 0.13 \pm 1.01$

$1.96 \pm 6.71 \quad 0.01 \pm 0.15 \quad 1.97 \pm 7.11 \quad 0.52 \pm 1.94$

$2.68 \pm 6.46 \quad 0.08 \pm 0.66 \quad 2.61 \pm 6.50 \quad 1.02 \pm 2.82$

$3.33 \pm 5.74 \quad 0.20 \pm 1.37 \quad 3.22 \pm 5.81 \quad 1.82 \pm 3.72$

$0.44 \pm 3.74 \quad 0 \quad 0.32 \pm 2.26 \quad 0$

$\begin{array}{lllll}0.57 \pm 3.02 & 0 & 0.49 \pm 2.57 & 0.08 \pm 0.69\end{array}$ 


\begin{tabular}{|c|c|c|c|c|c|c|c|}
\hline $\begin{array}{l}\text { Upper middle-class neighborhoods at } 600 \\
\mathrm{~m}\end{array}$ & dntcdad320 & $* * \S$ & $* * \S$ & $0.80 \pm 2.57$ & 0 & $0.76 \pm 2.37$ & $0.23 \pm 1.63$ \\
\hline $\begin{array}{l}\text { Upper middle-class neighborhoods at } 900 \\
\mathrm{~m}\end{array}$ & dntcdad330 & $* * \S$ & $* * \S$ & $1.22 \pm 2.84$ & 0 & $1.22 \pm 2.74$ & $0.32 \pm 2.17$ \\
\hline $\begin{array}{l}\text { Upper middle-class neighborhoods at } \\
1200 \mathrm{~m}\end{array}$ & dntcdad340 & $* *$ & $* * \S$ & $1.64 \pm 3.01$ & 0 & $1.65 \pm 2.97$ & $0.33 \pm 1.90$ \\
\hline Industrial area at $150 \mathrm{~m}$ & dntcdad405 & $* * \S$ & $* * \S$ & $1.68 \pm 6.54$ & 0 & $1.87 \pm 6.84$ & $0.22 \pm 1.69$ \\
\hline Industrial area at $300 \mathrm{~m}$ & dntcdad410 & $* * \S$ & & $2.67 \pm 7.46$ & 0 & $2.81 \pm 7.57$ & $1.01 \pm 3.40$ \\
\hline Industrial area at $600 \mathrm{~m}$ & dntcdad420 & $* *$ & & $3.14 \pm 5.71$ & $0.07 \pm 0.54$ & $3.12 \pm 5.72$ & $3.07 \pm 5.18$ \\
\hline Industrial area at $900 \mathrm{~m}$ & dntcdad430 & $* * \S$ & & $3.49 \pm 4.68$ & $0.32 \pm 1.18$ & $3.53 \pm 4.91$ & $3.50 \pm 4.21$ \\
\hline Industrial area at $1200 \mathrm{~m}$ & dntcdad440 & $* * \S$ & $* * \S$ & $4.38 \pm 4.76$ & $0.60 \pm 1.51$ & $4.42 \pm 5.01$ & $2.89 \pm 3.08$ \\
\hline \multicolumn{8}{|l|}{ (C) Environmental variables } \\
\hline Elevation & elevac & $* * \S$ & & $\begin{array}{l}139.51 \pm \\
9.37\end{array}$ & $\begin{array}{c}142.52 \pm \\
10.86\end{array}$ & $\begin{array}{l}139.80 \pm \\
9.29\end{array}$ & $\begin{array}{l}141.10 \pm \\
9.97\end{array}$ \\
\hline Slope & slope & & & $0.26 \pm 0.26$ & $0.50 \pm 1.47$ & $0.28 \pm 0.32$ & $0.32 \pm 0.59$ \\
\hline Soil type & suelo & $* * \S$ & $* * \S$ & $2 !$ & $2 i$ & $2 !$ & 21 \\
\hline
\end{tabular}

Note: Variables followed by $* * \S$ were used to build the various logistic regression models.

$\dagger S_{3000}$, sampling based on a growth surface of $3000 \mathrm{~m}$.

$\ddagger \mathrm{S}_{500}$, sampling based on a growth surface of $500 \mathrm{~m}$.

$\S$ Variables that were not strongly correlated with other variables (Spearman correlation coefficient < $0.65)$.

'Modal class for categorical variables.

$* * \mathrm{P}<0.01$, Mann-Whitney $U$ test.

$\mathrm{m}$ radius around the city's perimeter, hereafter called the potential urban growth surface (Fig. 2C, D). However, this was problematic because the urbanization process typically proceeded in an autocorrelated manner in blocks with a spatial scale larger than the $30 \times 30 \mathrm{~m}$ cell size used as the unit of analysis (Fig. 2A). We therefore used an alternative approach to construct the cells with a value of 0 for the dependent variable. This approach approximated the spatial structure of the observed cells with a value of 1 to reduce the problem of spatial autocorrelation. In short, we divided the area with growth into fragments with a maximum size of 150 cells $(13.5 \mathrm{ha})$ and distributed these fragments randomly without overlap within the potential urban growth surface (Fig. 2C,D). Typical construction units in Los Ángeles were not individual houses, but rather new housing developments or industrial facilities that comprised several hectares, i.e., larger than the $30 \times 30 \mathrm{~m}$ cells. A detailed description of the algorithm used can be found in Wiegand et al. (2006).

\section{Spatial autocorrelation and sampling scale}

Spatial autocorrelation of the dependent variable may lead to pseudoreplication because the data are not independent and will result in an increased power, which produces overfitted models. To evaluate the effect of autocorrelation and to define 
an appropriate sampling scale, a spatial autocorrelation analysis was done on the proportion of cells with growth. For this, the Pearson correlation coefficient $r_{\mathrm{P}}$ was calculated between variables $x(i)$ and $y(i)$, where $x(i)$ is the value of the dependent variable at cell $i$ and $y(i)$ is the mean value of the dependent variable inside a ring of radius $r$ and width of one cell around cell $i$. This correlation coefficient measures the spatial autocorrelation of variable $x$ with lag $d$ (Schadt et al. 2002, Naves et al. 2003). To reduce problems with severe spatial correlation, we determined the spatial lag $d$ at which growth was not strongly correlated, i.e., a correlation coefficient of $r_{\mathrm{P}}<0.65$, and selected only those cells that were sufficiently separated. For both urban growth surfaces, the correlation coefficient was $<0.65$ for a spatial lag of five or more cells (Fig. 3A,C). Thus, we reduced the effect of spatial autocorrelation by using a systematic sample of $5 \times$ 5 cells, i.e., retaining only cells that were separated by more than five cells, to represent the dependent variable (Fig. 3A,C). The values and geographic positions of the independent variables were then chosen from the 463 and 472 remaining sample cells for the 3000- and 500-m growth surfaces, respectively (Fig. 3B,D).

\section{Univariate analyses}

Significant differences in the mean values of the independent variables between cells with and without growth were evaluated using the nonparametric Mann-Whitney $U$ test. This allowed us to exclude some variables from the regression analysis. Problems with multicolinearity between independent variables were avoided by retaining the variable that best explained the observed growth from pairs of highly correlated, i.e., Spearman correlation coefficient $>0.65$, independent variables.

\section{Multivariate analyses}

Variables from 1978 were used to adjust the logistic regression for growth during the period 1978-1992. To reduce the high number of possible models, we performed four different regression analyses that corresponded to different a priori selected hypotheses and model structures. In the first model, we hypothesized that environmental variables and distance variables would be sufficient to describe the observed urban growth. This corresponds to traditional approaches in regression modeling (e.g., LaGro and DeGloria 1992, Pijanowski et al. 2002,
Allen and Lu 2003). In the second model, we hypothesized that environmental variables and neighborhood density variables at one appropriate spatial scale would be sufficient to describe the observed urban growth. To determine the appropriate spatial scale of the neighborhood variables, we repeated the analysis for all five scales selected. This approach was recently used in wildlife habitat suitability modeling (e.g., Schadt et al. 2002, Naves et al. 2003). In the third model, we tested whether the inclusion of both distance and neighborhood density variables together with environmental variables would describe the observed urban growth better than the first two models. In the fourth model, we allowed environmental variables, distance variables, and neighborhood density variables at different spatial scales.

To evaluate which model and spatial scales best explained the observed growth pattern, we performed a variable reduction approach combining stepwise ordinal logistic regression and best subset selection based on the Akaike information criterion (AIC; Burnham and Anderson 1998, Shtatland et al. 2001). We first used the stepwise model selection technique for each of the 12 model structures and spatial scales, if appropriate, taking the reduction of the likelihood ratio as a criterion. Variables within model structures were further reduced if they were highly correlated; in the combined models, i.e., the third and fourth models, we used only variables selected in a simpler model, i.e., the first or second model.

To select from among the remaining models the scale and model that resulted in the best fit to the data, we used the AIC. The AIC penalizes model complexity, i.e., the number of explanatory variables used in the model (Burnham and Anderson 1998). To aid in the interpretation of the model, we also used Nagelkerke's $R^{2}$ (Allen and Lu 2003). We repeated all analyses for the two random growth models, i.e., models based on the 3000-m growth surface and models based on the 500-m growth surface. The statistical analysis was performed using SPSS for Windows, release 10.0.5.

\section{Prediction}

The results of the regression analysis were used to predict the probability of urban growth in 19921998 using the parameters of those models that produced the best global fit according to the AIC. 
Fig. 3. (A) Spatial autocorrelation and scale definition for the 3000-m urban growth surface and (B) systematic sampling of $5 \times 5$ cells used as the dependent variable based on the $3000-\mathrm{m}$ urban growth surface. (C) Spatial autocorrelation and scale definition for the 500-m urban growth surface and (D) systematic sampling of $5 \times 5$ cells used as the dependent variable based on the 500 -m urban growth surface.

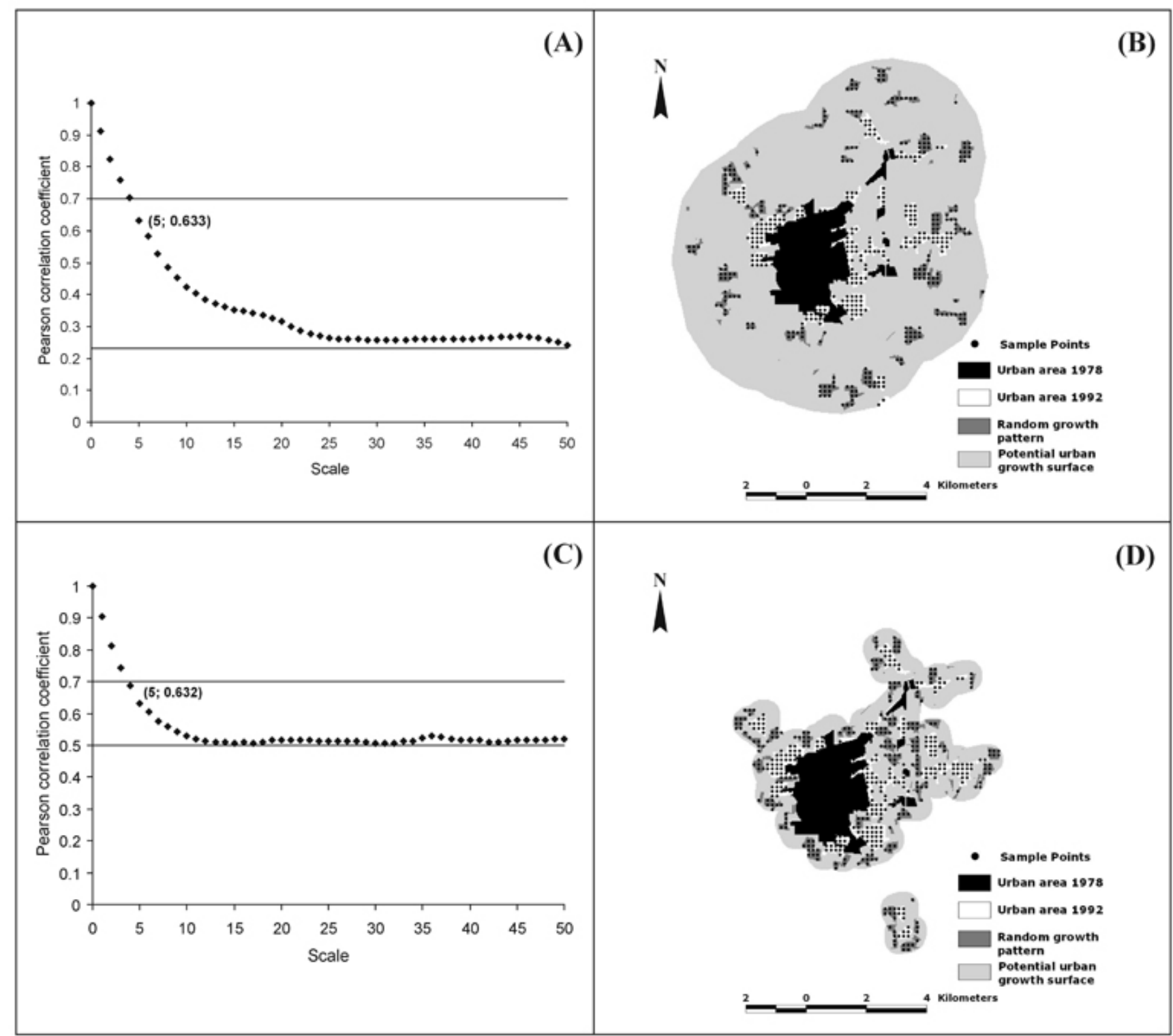


The predictions were evaluated using transition matrices that compared the predicted growth from a given model $(P>0.5)$ with that observed in the second study period of 1992-1998.

\section{RESULTS}

\section{Urban growth factors and variables}

The following six variables were selected as independent variables explaining the urban growth process: roadway networks, amenities and services, residential and industrial areas, bodies of water, soil type, and topographic characteristics. These basic variables were used to generate a total of 52 derived variables, which were grouped according to their relationship with the areas of observed urban growth in terms of distance variables, neighborhood variables, and environmental variables (Table 1).

The superposition of the urban growth areas over independent variables showed the growth pattern to be closely related to the distance and density of certain elements such as roads, amenities, and residential and industrial areas and to the characteristics of some environmental and topographic factors. For example, all the sampled cells with urban growth were distributed within a range of 0 to $990 \mathrm{~m}$ from the urban roadway network, and nearly half of these were located at distances of less than $124 \mathrm{~m}$ from roads. Likewise, the presence of certain types of soil favored urban growth; growth occurred most frequently on type 2 soil, which is high-quality, productive agricultural soil (Table 1).

\section{Dynamics of urban land-use change}

By analyzing the results of the transition matrices (Table 2), it can be seen that the constructed urban surface grew $65.5 \%$ between 1978 and 1992 with respect to the 1978 urban area, spreading urban use onto 533.3 ha of what was once predominantly agricultural land. In the following period (19921998), urban growth was $34 \%$ with respect to the 1992 urban area, increasing urban usage by 457.8 ha and once again occupying former agricultural land. The rate of change of new urban land incorporated into Los Ángeles between 1992 and 1998 at $76.3 \mathrm{ha} / \mathrm{yr}$ is double that between 1978 and 1992 at $38.1 \mathrm{ha} / \mathrm{yr}$.

\section{Urban growth modeling}

Analysis of the observed growth pattern for 19781992 for the 3000-m urban growth surface using a Mann-Whitney test revealed that only five of the 52 variables considered did not show significant differences between no growth and growth $\left(S_{3000}\right.$ in Table 1). For example, the mean distance between cells with urban growth and rivers was not significantly different from the mean distance between cells with urban growth and randomly distributed cells without urban growth $(P=0.7 ; \alpha$ $=0.01)$. The same was true for rural roads, slope, and the two neighborhood variables of a radius of 5 and $150 \mathrm{~m}$ (Table 1). Thus, five variables were eliminated. Additionally, seven distance and 14 neighborhood variables were eliminated because they were highly correlated with the remaining variables (Table 1). The 12 logistic regression models were adjusted using the remaining 26 variables.

When repeating the above analysis for the 500-m urban growth surface, we found that that 21 of the 52 variables considered did not show significant differences between cells with and without urban growth $\left(S_{500}\right.$ in Table 1$)$. These variables were related to, e.g., the distance to highways and railroads, amenities and services, and the density of middle-class neighborhoods and industrial areas. Thus, 21 variables were eliminated. Additionally, three distance and seven neighborhood variables were eliminated because they were highly correlated with the remaining variables (Table 1). The 12 logistic regression models were adjusted using the remaining variables.

\section{Models with distance variables}

Model $\mathrm{m} 1_{\mathrm{d}}$, based on the 3000-m growth surface, contained six significant variables and reached an $R^{2}$ of 0.67 (Table 3 ). The variables that contributed most to the probability of urban growth were: distance from access roads, distance from highways, distance from the urban roadway network, and distance from the urban perimeter. Of these, distance from highways and distance from access roads best explained growth in the fit to model $\mathrm{m} 1_{\mathrm{d}}$. The environmental variables of soil and elevation were also selected; they significantly explained a large proportion of the model variance (Table 3A).

According to the adjusted parameters, $\beta_{(i)}$, of model $\mathrm{m} 1_{\mathrm{d}}$, a negative relationship was observed between 
Table 2. Transition matrices of urban land use for (A) 1978 to 1992 and (B) 1992 to 1998. Values indicate the number of urban and nonurban cells; the matrix diagonal indicates cells that did not undergo change during the study period.

(A)

1978

\begin{tabular}{llccc}
\cline { 3 - 4 } & & Nonurban & Urban & Total \\
\hline 1992 & Nonurban & 284,764 & & 284,764 \\
& Urban & 5925 & 9041 & 14,966 \\
& Total & 290,689 & 9041 & 299,730 \\
& & & \\
\hline
\end{tabular}

(B)

1992

\begin{tabular}{llccc}
\cline { 3 - 4 } & & Nonurban & Urban & Total \\
\hline 1998 & Nonurban & 279,677 & & 279,677 \\
& Urban & 5087 & 14,966 & 20,053 \\
& Total & 284,764 & 14,966 & 299,730
\end{tabular}

the probability of urban growth and the distance from certain elements. In other words, the greater the distance, the lower the probability of land-use change. The variables related to distance from commercial, educational, and health amenities; financial services; and the city's historic downtown were not entered into the model because they were highly correlated with the variable of distance from the urban perimeter and therefore were implicitly incorporated within the latter variable. The same was true for distance from lower-, middle-, and upper-middle-class neighborhoods (Table 3A).

The analogous model fit using the 500-m urban growth surface was considerablely poorer, yielding an $R^{2}$ of 0.17 and an Akaike information criterion (AIC) of 596, which was greater than the AIC of 332 of the model fit using the 3000-m urban growth surface (Table 4A). Interestingly, the highly significant variables of the $3000-\mathrm{m}$ model of the distance to access roads and the distance to highways did not enter at the 500-m scale. The remaining variables of model $\mathrm{m} 1_{\mathrm{d}}$ that were able to discriminate between growth and no growth were: distance from the urban roadway network, distance from the urban perimeter, and soil (Table 4A).

\section{Models with neighborhood variables}

The model based on the 3000-m urban growth surface presenting the best global fit with respect to the environmental and neighborhood variables were estimated from variables constructed using a 40-cell radius $(1200 \mathrm{~m})$ yielding an $R^{2}$ of 0.58 . The AIC decreased with increasing scale from 495.5 in model $\mathrm{m} 2{ }_{\mathrm{e} 5}$ with a $300-\mathrm{m}$ neighborhood to 384.5 in model $\mathrm{m}_{\mathrm{e} 40}$ with a $1200-\mathrm{m}$ neighborhood (Table $3 \mathrm{~B}$ ). The model $\mathrm{m}_{\mathrm{e} 20}$ with an AIC of 392, adjusted using variables from the 20 -cell radius $(600 \mathrm{~m})$, was also noteworthy. However, the models using only environmental and neighborhood variables yielded a poorer fit than model $\mathrm{m} 1_{\mathrm{d}}\left(\mathrm{AIC}=332, R^{2}=0.67\right)$, which was constructed using only distance and environmental variables (Table 3B). 
Table 3. Results of the adjustment of the logistic regression using the 3000-m random growth model according to variable blocks.

\begin{tabular}{|c|c|c|c|c|c|c|c|}
\hline \multirow[b]{2}{*}{ Model $\dagger$} & \multirow[b]{2}{*}{$\mathrm{AIC} \ddagger$} & \multirow[b]{2}{*}{$R^{2} \S$} & \multicolumn{5}{|c|}{ Model parameters } \\
\hline & & & Variable & $\beta(i)$ & $\begin{array}{l}\text { Standard } \\
\text { error }\end{array}$ & Wald & $P$ \\
\hline \multicolumn{8}{|c|}{ (A) Distance variables only } \\
\hline \multirow[t]{7}{*}{$\mathrm{m} 1_{\mathrm{d}}$} & 332.0 & 0.6694 & $\begin{array}{l}\text { Distance from } \\
\text { urban road } \\
\text { network }\end{array}$ & -0.0026 & 0.0006 & 18.07 & 0.00002 \\
\hline & & & $\begin{array}{l}\text { Distance from } \\
\text { urban perimeter }\end{array}$ & -0.0011 & 0.0003 & 16.12 & 0.00006 \\
\hline & & & $\begin{array}{l}\text { Distance from } \\
\text { highways }\end{array}$ & -0.0012 & 0.0002 & 25.69 & $<0.00001$ \\
\hline & & & $\begin{array}{l}\text { Distance from } \\
\text { access roads }\end{array}$ & -0.0013 & 0.0003 & 25.90 & $<0.00001$ \\
\hline & & & Elevation & -0.1218 & 0.0341 & 12.78 & 0.00035 \\
\hline & & & Soil type & -0.2302 & 0.0774 & 8.85 & 0.00293 \\
\hline & & & $\beta_{0}$ & 23.8128 & 5.2988 & 20.20 & 0.00001 \\
\hline
\end{tabular}

(B) Neighborhood variables only, with fixed scale

\begin{tabular}{|c|c|c|c|c|c|c|c|}
\hline \multirow[t]{4}{*}{$\mathrm{m} 2_{\mathrm{e} 5}$} & 495.3 & 0.3763 & $\begin{array}{l}\text { Density of } \\
\text { urban road } \\
\text { network at } 150 \\
\mathrm{~m}\end{array}$ & 9.4994 & 1.6703 & 32.34 & $<0.00001$ \\
\hline & & & $\begin{array}{l}\text { Density of } \\
\text { urban area at } \\
150 \mathrm{~m}\end{array}$ & 617.0347 & 1135.3707 & 0.30 & 0.58681 \\
\hline & & & Soil type & -0.3165 & 0.0706 & 20.09 & 0.00001 \\
\hline & & & $\beta_{0}$ & 0.2213 & 0.2233 & 0.98 & 0.32151 \\
\hline \multirow[t]{4}{*}{$\mathrm{m} 3 \mathrm{e}_{\mathrm{e} 10}$} & 431.6 & 0.4992 & $\begin{array}{l}\text { Density of } \\
\text { urban road } \\
\text { network at } 300 \\
\mathrm{~m}\end{array}$ & 19.3921 & 3.0979 & 39.18 & $<0.00001$ \\
\hline & & & $\begin{array}{l}\text { Density of } \\
\text { urban area at } \\
300 \mathrm{~m}\end{array}$ & 104.0760 & 34.2814 & 9.22 & 0.00240 \\
\hline & & & Soil type & -0.3411 & 0.0821 & 17.27 & 0.00003 \\
\hline & & & $\beta_{0}$ & -0.3184 & 0.2642 & 1.45 & 0.22811 \\
\hline $\mathrm{m} 4_{\mathrm{e} 20}$ & 392.0 & 0.5677 & $\begin{array}{l}\text { Density of } \\
\text { urban road } \\
\text { network at } 600 \\
\mathrm{~m}\end{array}$ & 29.2041 & 6.0233 & 23.51 & $<0.00001$ \\
\hline
\end{tabular}




\begin{tabular}{|c|c|c|c|c|c|c|c|}
\hline & & & $\begin{array}{l}\text { Density of } \\
\text { urban area at } \\
600 \mathrm{~m}\end{array}$ & 33.4325 & 5.9790 & 31.27 & $<0.00001$ \\
\hline & & & Soil type & -0.4111 & 0.0940 & 19.14 & 0.00001 \\
\hline & & & $\beta_{0}$ & -0.6162 & 0.3118 & 3.90 & 0.04815 \\
\hline \multirow[t]{4}{*}{$\mathrm{m} 5_{\mathrm{e} 30}$} & 403.2 & 0.5489 & $\begin{array}{l}\text { Density of } \\
\text { urban road } \\
\text { network at } 900 \\
\mathrm{~m}\end{array}$ & 73.6928 & 8.8314 & 69.63 & $<0.00001$ \\
\hline & & & $\begin{array}{l}\text { Density of } \\
\text { urban area at } \\
900 \mathrm{~m}\end{array}$ & 21.5670 & 7.1991 & 8.97 & 0.00274 \\
\hline & & & Soil type & -0.3979 & 0.0801 & 24.65 & $<0.00001$ \\
\hline & & & $\beta_{0}$ & -2.0723 & 0.3524 & 34.59 & $<0.00001$ \\
\hline \multirow[t]{4}{*}{$\mathrm{m} 6_{\mathrm{e} 40}$} & 384.5 & 0.5800 & $\begin{array}{l}\text { Density of } \\
\text { urban road } \\
\text { network at } \\
1200 \mathrm{~m}\end{array}$ & 87.4612 & 11.3259 & 59.63 & $<0.00001$ \\
\hline & & & $\begin{array}{l}\text { Density of } \\
\text { industrial area } \\
\text { at } 1200 \mathrm{~m}\end{array}$ & 19.5602 & 6.6540 & 8.64 & 0.00329 \\
\hline & & & Soil type & -0.4020 & 0.0867 & 21.49 & $<0.00001$ \\
\hline & & & $\beta_{0}$ & -2.7073 & 0.4129 & 42.98 & $<0.00001$ \\
\hline \multicolumn{8}{|c|}{ (C) Distance variables and neighborhood variables, with fixed scale } \\
\hline \multirow[t]{8}{*}{$\mathrm{m} 7_{\mathrm{de} 05}$} & 318.3 & 0.6916 & $\begin{array}{l}\text { Distance from } \\
\text { urban perimeter }\end{array}$ & -0.0008 & 0.0003 & 7.15 & 0.00751 \\
\hline & & & $\begin{array}{l}\text { Distance from } \\
\text { highways }\end{array}$ & -0.0012 & 0.0002 & 26.76 & $<0.00001$ \\
\hline & & & $\begin{array}{l}\text { Distance from } \\
\text { access roads }\end{array}$ & -0.0015 & 0.0003 & 32.48 & $<0.00001$ \\
\hline & & & Elevation & -0.1254 & 0.0333 & 14.18 & 0.00017 \\
\hline & & & Soil type & -0.2608 & 0.0881 & 8.75 & 0.00309 \\
\hline & & & $\begin{array}{l}\text { Density of } \\
\text { urban road } \\
\text { network at } 150 \\
\mathrm{~m}\end{array}$ & 9.1671 & 2.3453 & 15.28 & 0.00009 \\
\hline & & & $\begin{array}{l}\text { Density of } \\
\text { urban area at } \\
150 \mathrm{~m}\end{array}$ & 361.6225 & 1105.3059 & 0.11 & 0.74354 \\
\hline & & & $\beta_{0}$ & 22.9483 & 5.2292 & 19.26 & 0.00001 \\
\hline \multirow[t]{2}{*}{$\mathrm{m} 8_{\mathrm{de} 10}$} & 300.1 & 0.7136 & $\begin{array}{l}\text { Distance from } \\
\text { highways }\end{array}$ & -0.0015 & 0.0002 & 46.40 & $<0.00001$ \\
\hline & & & $\begin{array}{l}\text { Distance from } \\
\text { access roads }\end{array}$ & -0.0018 & 0.0002 & 64.15 & $<0.00001$ \\
\hline
\end{tabular}




\begin{tabular}{|c|c|c|c|c|c|c|c|}
\hline & & & Elevation & -0.1532 & 0.0296 & 26.73 & $<0.00001$ \\
\hline & & & Soil type & -0.2899 & 0.0972 & 8.89 & 0.00286 \\
\hline & & & $\begin{array}{l}\text { Density of } \\
\text { urban road } \\
\text { network at } 300 \\
\text { m }\end{array}$ & 17.7731 & 3.8258 & 21.58 & $<0.00001$ \\
\hline & & & $\begin{array}{l}\text { Density of } \\
\text { urban area at } \\
300 \mathrm{~m}\end{array}$ & 66.9658 & 27.5644 & 5.90 & 0.01512 \\
\hline & & & $\beta_{0}$ & 26.4003 & 4.8024 & 30.22 & $<0.00001$ \\
\hline \multirow[t]{7}{*}{$\mathrm{m} 9_{\mathrm{de} 20}$} & 306.4 & 0.7052 & $\begin{array}{l}\text { Distance from } \\
\text { highways }\end{array}$ & -0.0013 & 0.0002 & 34.67 & $<0.00001$ \\
\hline & & & $\begin{array}{l}\text { Distance from } \\
\text { access roads }\end{array}$ & -0.0016 & 0.0002 & 48.88 & $<0.00001$ \\
\hline & & & Elevation & -0.1197 & 0.0306 & 15.33 & 0.00009 \\
\hline & & & Soil type & -0.3348 & 0.1054 & 10.08 & 0.00150 \\
\hline & & & $\begin{array}{l}\text { Density of } \\
\text { urban road } \\
\text { network at } 600 \\
\mathrm{~m}\end{array}$ & 26.3141 & 7.3612 & 12.78 & 0.00035 \\
\hline & & & $\begin{array}{l}\text { Density of } \\
\text { urban area at } \\
600 \mathrm{~m}\end{array}$ & 20.5620 & 5.5627 & 13.66 & 0.00022 \\
\hline & & & $\beta_{0}$ & 20.8131 & 4.9719 & 17.52 & 0.00003 \\
\hline \multirow[t]{6}{*}{$\mathrm{m} 10_{\mathrm{de} 30}$} & 315.7 & 0.6896 & $\begin{array}{l}\text { Distance from } \\
\text { highways }\end{array}$ & -0.0014 & 0.0002 & 40.86 & $<0.00001$ \\
\hline & & & $\begin{array}{l}\text { Distance from } \\
\text { access roads }\end{array}$ & -0.0017 & 0.0002 & 55.52 & $<0.00001$ \\
\hline & & & Elevation & -0.1438 & 0.0307 & 22.01 & $<0.00001$ \\
\hline & & & Soil type & -0.3598 & 0.0941 & 14.63 & 0.00013 \\
\hline & & & $\begin{array}{l}\text { Density of } \\
\text { urban road } \\
\text { network at } 900 \\
\text { m }\end{array}$ & 61.7723 & 10.5389 & 34.36 & $<0.00001$ \\
\hline & & & $\beta_{0}$ & 23.6957 & 5.0295 & 22.20 & $<0.00001$ \\
\hline \multirow[t]{5}{*}{$\mathrm{m} 11_{\mathrm{de} 40}$} & 301.1 & 0.7123 & $\begin{array}{l}\text { Distance from } \\
\text { highways }\end{array}$ & -0.0018 & 0.0003 & 37.12 & $<0.00001$ \\
\hline & & & $\begin{array}{l}\text { Distance from } \\
\text { access roads }\end{array}$ & -0.0020 & 0.0003 & 52.39 & $<0.00001$ \\
\hline & & & Elevation & -0.1629 & 0.0364 & 19.98 & 0.00001 \\
\hline & & & Soil type & -0.3648 & 0.1011 & 13.03 & 0.00031 \\
\hline & & & $\begin{array}{l}\text { Density of } \\
\text { urban road } \\
\text { network at } \\
1200 \mathrm{~m}\end{array}$ & 96.8332 & 15.0026 & 41.66 & $<0.00001$ \\
\hline
\end{tabular}




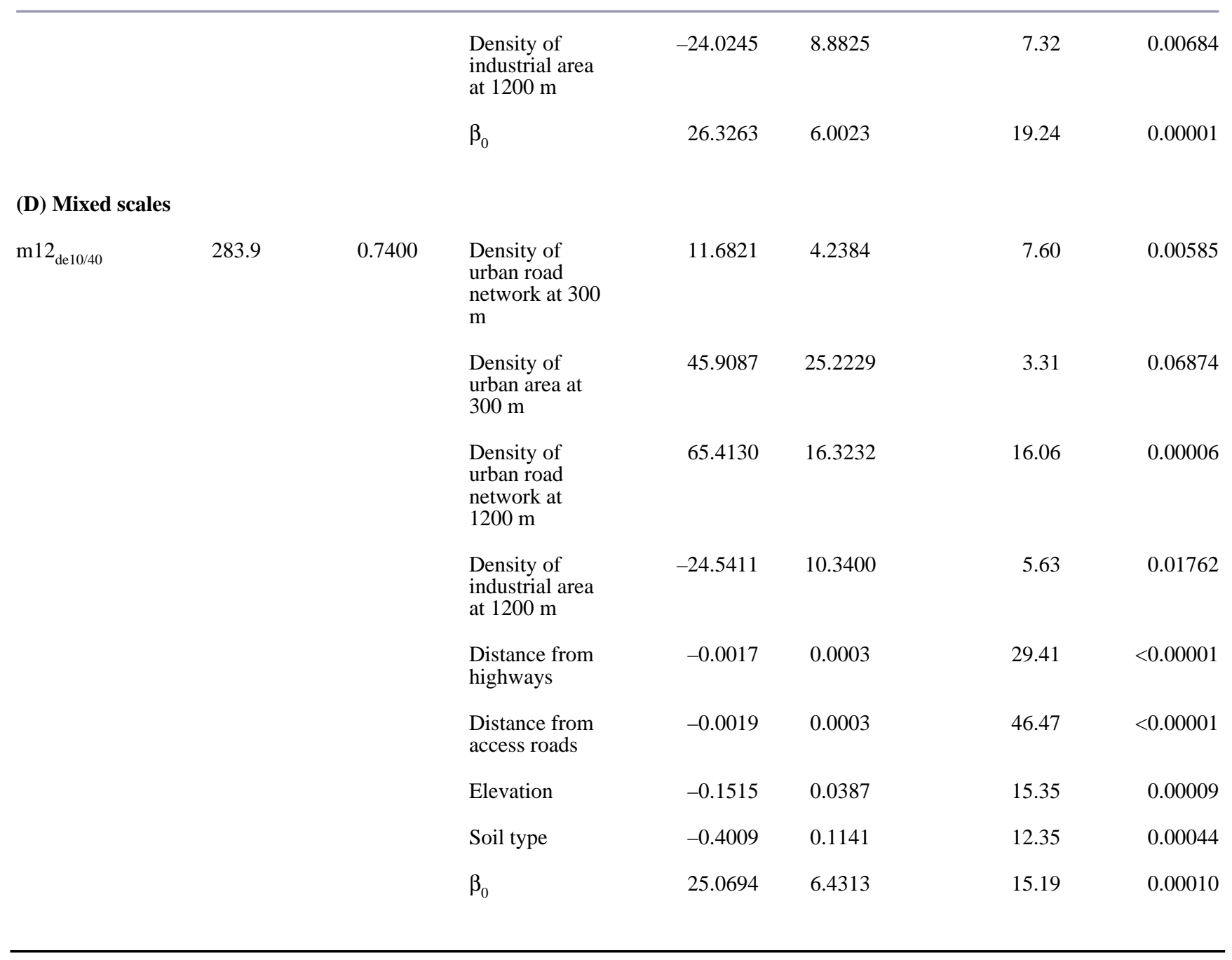

$\dagger$ Models: $m i_{\mathrm{d}}$, models adjusted using distance variables; $m i_{\mathrm{e} j}$, models adjusted using neighborhood variables by scale; $m i_{\mathrm{dej}}$, models adjusted using distance and neighborhood variables; $m i_{\mathrm{dej}} / k$, models adjusted using distance and neighborhood variables with combined scales; $i$ is the model number and $j$ and $k$ are scale identifiers, with $j$ and $k=150,300,600,900$, or $1200 \mathrm{~m}$.

$\$$ Akaike information criterion.

$\S$ Nagelkerke's $R^{2}$.

Again, the models based on the 500-m urban growth surface were much poorer than the corresponding models based on the 3000-m urban growth surface. However, at neighborhoods of 150 and $300 \mathrm{~m}$, the models improved compared to the model using only distance variables. The significant variables were analogous to those in model $\mathrm{m} 1_{\mathrm{d}}$ and were related to the urban road network, the urban area, and the soil (Table 4B).
Models integrating distance and neighborhood variables

The integration of distance and neighborhood variables substantially improved the global fit of the models based on the 3000-m urban growth surface compared to model $\mathrm{m} 1_{\mathrm{d}}$, increasing the $R^{2}$ to 0.71 and decreasing the AIC from 332 in $\mathrm{m} 1_{\mathrm{d}}$ to 300.1 in $\mathrm{m} 8_{\mathrm{de} 10}$. The variables of distance from access roads and distance from highways best predicted 
Table 4. Results of the adjustment of the logistic regression using the 500-m random growth model according to variable blocks.

\begin{tabular}{|c|c|c|c|c|c|c|c|}
\hline \multirow[b]{2}{*}{ Model $\dagger$} & \multirow[b]{2}{*}{$\mathrm{AIC} \ddagger$} & \multirow[b]{2}{*}{$R^{2} \S$} & \multicolumn{5}{|c|}{ Model parameters } \\
\hline & & & Variable & $\beta(i)$ & Standard error & Wald & $P$ \\
\hline \multicolumn{8}{|c|}{ (A) Distance variables only } \\
\hline \multirow[t]{4}{*}{$\mathrm{m} 1_{\mathrm{d}}$} & 595.7 & 0.1729 & $\begin{array}{l}\text { Distance from } \\
\text { urban road } \\
\text { network }\end{array}$ & -0.0030 & 0.0006 & 28.29 & $<0.00001$ \\
\hline & & & $\begin{array}{l}\text { Distance from } \\
\text { urban perimeter }\end{array}$ & -0.0005 & 0.0001 & 16.99 & 0.00004 \\
\hline & & & Soil type & -0.1790 & 0.0514 & 12.13 & 0.00050 \\
\hline & & & $\beta_{0}$ & 1.6829 & 0.2464 & 46.63 & $<0.00001$ \\
\hline
\end{tabular}

(B) Neighborhood variables only, with fixed scale

\begin{tabular}{|c|c|c|c|c|c|c|c|}
\hline \multirow[t]{4}{*}{$\mathrm{m} 2_{\mathrm{e} 5}$} & 571.9 & 0.2300 & $\begin{array}{l}\text { Density of } \\
\text { urban road } \\
\text { network at } 150 \\
\mathrm{~m}\end{array}$ & 7.9491 & 1.5460 & 26.44 & $<0.00001$ \\
\hline & & & $\begin{array}{l}\text { Density of } \\
\text { urban area at } \\
150 \mathrm{~m}\end{array}$ & 11.6128 & 3.0429 & 14.56 & 0.00014 \\
\hline & & & Soil type & -0.1776 & 0.0537 & 10.93 & 0.00095 \\
\hline & & & $\beta_{0}$ & -0.0091 & 0.2020 & 0.00 & 0.96412 \\
\hline \multirow[t]{4}{*}{$\mathrm{m} 3_{\mathrm{e} 10}$} & 570.6 & 0.2329 & $\begin{array}{l}\text { Density of } \\
\text { urban road } \\
\text { network at } 300 \\
\text { m }\end{array}$ & 13.5780 & 2.4692 & 30.24 & $<0.00001$ \\
\hline & & & $\begin{array}{l}\text { Density of } \\
\text { urban area at } \\
300 \mathrm{~m}\end{array}$ & 5.9422 & 1.4281 & 17.31 & 0.00003 \\
\hline & & & Soil type & -0.1856 & 0.0539 & 11.86 & 0.00057 \\
\hline & & & $\beta_{0}$ & -0.3294 & 0.2202 & 2.24 & 0.13479 \\
\hline \multirow[t]{4}{*}{$\mathrm{m} 4_{\mathrm{e} 20}$} & 614.8 & 0.1250 & $\begin{array}{l}\text { Density of } \\
\text { urban road } \\
\text { network at } 600 \\
\mathrm{~m}\end{array}$ & 10.5500 & 4.3290 & 5.94 & 0.01481 \\
\hline & & & $\begin{array}{l}\text { Density of } \\
\text { urban area at } \\
600 \mathrm{~m}\end{array}$ & 2.3884 & 0.9157 & 6.80 & 0.00910 \\
\hline & & & Soil type & -0.1994 & 0.0512 & 15.13 & 0.00010 \\
\hline & & & $\beta_{0}$ & -0.1183 & 0.2511 & 0.22 & 0.63773 \\
\hline
\end{tabular}




\begin{tabular}{|c|c|c|c|c|c|c|c|}
\hline \multirow[t]{4}{*}{$\mathrm{m} 5_{\mathrm{e} 30}$} & 615.6 & 0.1230 & $\begin{array}{l}\text { Density of } \\
\text { urban road } \\
\text { network at } 900 \\
\mathrm{~m}\end{array}$ & 16.8090 & 5.2836 & 10.12 & 0.00147 \\
\hline & & & $\begin{array}{l}\text { Density of } \\
\text { upper middle- } \\
\text { class neighbor- } \\
\text { hoods at } 900 \mathrm{~m}\end{array}$ & 11.5866 & 5.6784 & 4.16 & 0.04130 \\
\hline & & & Soil type & -0.2080 & 0.0510 & 16.62 & 0.00005 \\
\hline & & & $\beta_{0}$ & -0.2930 & 0.3075 & 0.91 & 0.34070 \\
\hline \multirow[t]{4}{*}{$\mathrm{m} 6_{\mathrm{e} 40}$} & 599.4 & 0.1638 & $\begin{array}{l}\text { Density of } \\
\text { urban road } \\
\text { network at } \\
1200 \mathrm{~m}\end{array}$ & 19.1889 & 6.6552 & 8.31 & 0.00394 \\
\hline & & & $\begin{array}{l}\text { Density of } \\
\text { upper middle- } \\
\text { class neighbor- } \\
\text { hoods at } 1200 \\
\mathrm{~m}\end{array}$ & 16.1304 & 6.8802 & 5.50 & 0.01905 \\
\hline & & & Soil type & -0.2014 & 0.0520 & 15.00 & 0.00011 \\
\hline & & & $\beta_{0}$ & -0.4766 & 0.3546 & 1.81 & 0.17897 \\
\hline
\end{tabular}

(C) Distance variables and neighborhood variables, with fixed scale

\begin{tabular}{|c|c|c|c|c|c|c|c|}
\hline \multirow[t]{6}{*}{$\mathrm{m} 7_{\text {de } 05}$} & 562.9 & 0.2691 & $\begin{array}{l}\text { Density of } \\
\text { urban road } \\
\text { network at } 150 \\
\mathrm{~m}\end{array}$ & 8.6128 & 1.6024 & 28.89 & $<0.00001$ \\
\hline & & & $\begin{array}{l}\text { Density of } \\
\text { urban area at } \\
150 \mathrm{~m}\end{array}$ & 10.1741 & 2.9501 & 11.89 & 0.00056 \\
\hline & & & $\begin{array}{l}\text { Distance from } \\
\text { access roads }\end{array}$ & -0.0004 & 0.0001 & 13.01 & 0.00031 \\
\hline & & & $\begin{array}{l}\text { Distance from } \\
\text { urban roads }\end{array}$ & -0.0002 & 0.0001 & 4.66 & 0.03083 \\
\hline & & & Soil type & -0.1825 & 0.0544 & 11.26 & 0.00079 \\
\hline & & & $\beta_{0}$ & 0.6118 & 0.2731 & 5.02 & 0.02504 \\
\hline \multirow[t]{5}{*}{$\mathrm{m} 8_{\mathrm{de} 10}$} & 565.9 & 0.2577 & $\begin{array}{l}\text { Density of } \\
\text { urban road } \\
\text { network at } 300 \\
\mathrm{~m}\end{array}$ & 14.5090 & 2.5187 & 33.18 & $<0.00001$ \\
\hline & & & $\begin{array}{l}\text { Density of } \\
\text { urban area at } \\
300 \mathrm{~m}\end{array}$ & 5.4364 & 1.4090 & 14.89 & 0.00011 \\
\hline & & & $\begin{array}{l}\text { Distance from } \\
\text { access roads }\end{array}$ & -0.0003 & 0.0001 & 9.96 & 0.00160 \\
\hline & & & Soil type & -0.1772 & 0.0538 & 10.86 & 0.00098 \\
\hline & & & $\beta_{0}$ & -0.0815 & 0.2339 & 0.12 & 0.72755 \\
\hline
\end{tabular}




\begin{tabular}{|c|c|c|c|c|c|c|c|}
\hline \multirow[t]{5}{*}{$\mathrm{m} 9_{\mathrm{de} 20}$} & 593.2 & 0.1838 & $\begin{array}{l}\text { Density of } \\
\text { urban area at } \\
600 \mathrm{~m}\end{array}$ & 1.9142 & 0.9414 & 4.13 & 0.04202 \\
\hline & & & $\begin{array}{l}\text { Distance from } \\
\text { urban road } \\
\text { network }\end{array}$ & -0.0028 & 0.0006 & 24.18 & 0.00000 \\
\hline & & & $\begin{array}{l}\text { Distance from } \\
\text { urban perimeter }\end{array}$ & -0.0003 & 0.0001 & 5.48 & 0.01922 \\
\hline & & & Soil type & -0.1745 & 0.0515 & 11.47 & 0.00071 \\
\hline & & & $\beta_{0}$ & 1.3189 & 0.2983 & 19.55 & 0.00001 \\
\hline \multirow[t]{5}{*}{$\mathrm{m} 10_{\mathrm{de} 30}$} & 589.3 & 0.1934 & $\begin{array}{l}\text { Density of } \\
\text { upper middle- } \\
\text { class neighbor- } \\
\text { hoods at } 900 \mathrm{~m}\end{array}$ & 13.9404 & 5.4899 & 6.45 & 0.01111 \\
\hline & & & $\begin{array}{l}\text { Distance from } \\
\text { urban road } \\
\text { network }\end{array}$ & -0.0029 & 0.0006 & 26.52 & $<0.00001$ \\
\hline & & & $\begin{array}{l}\text { Distance from } \\
\text { urban perimeter }\end{array}$ & -0.0004 & 0.0001 & 11.27 & 0.00079 \\
\hline & & & Soil type & -0.1798 & 0.0519 & 12.03 & 0.00052 \\
\hline & & & $\beta_{0}$ & 1.5086 & 0.2529 & 35.58 & $<0.00001$ \\
\hline \multirow[t]{5}{*}{$\mathrm{m} 11_{\mathrm{de} 40}$} & 581.5 & 0.2216 & $\begin{array}{l}\text { Density of } \\
\text { upper middle- } \\
\text { class neighbor- } \\
\text { hoods at } 1200 \\
\mathrm{~m}\end{array}$ & 25.4850 & 5.9750 & 18.19 & 0.00002 \\
\hline & & & $\begin{array}{l}\text { Distance from } \\
\text { urban road } \\
\text { network }\end{array}$ & -0.0027 & 0.0006 & 22.96 & $<0.00001$ \\
\hline & & & $\begin{array}{l}\text { Distance from } \\
\text { access roads }\end{array}$ & -0.0003 & 0.0001 & 6.53 & 0.01058 \\
\hline & & & Soil type & -0.1860 & 0.0525 & 12.54 & 0.00040 \\
\hline & & & $\beta_{0}$ & 1.2578 & 0.2446 & 26.44 & $<0.00001$ \\
\hline
\end{tabular}

\section{(D) Mixed scales}

\begin{tabular}{|c|c|c|c|c|c|c|c|}
\hline \multirow[t]{3}{*}{$\mathrm{m} 12_{\mathrm{de} 10 / 40}$} & \multirow[t]{3}{*}{545.5} & \multirow[t]{3}{*}{0.3031} & $\begin{array}{l}\text { Density of } \\
\text { urban road } \\
\text { network at } 300 \\
\mathrm{~m}\end{array}$ & 14.8692 & 2.5883 & 33.00 & $<0.00001$ \\
\hline & & & $\begin{array}{l}\text { Density of } \\
\text { urban area at } \\
300 \mathrm{~m}\end{array}$ & 4.9017 & 1.5274 & 10.30 & 0.00133 \\
\hline & & & $\begin{array}{l}\text { Density of } \\
\text { upper middle- } \\
\text { class neighbor- } \\
\text { hoods at } 1200 \\
\mathrm{~m}\end{array}$ & 30.8957 & 8.2085 & 14.17 & 0.00017 \\
\hline
\end{tabular}




$\begin{array}{lcccc}\begin{array}{l}\text { Density of } \\ \text { industrial area } \\ \text { at } 1200 \mathrm{~m}\end{array} & -8.0127 & 4.0362 & 3.94 & 0.04712 \\ \begin{array}{l}\text { Distance from } \\ \text { access roads }\end{array} & -0.0003 & 0.0001 & 9.71 & 0.00183 \\ \text { Soil type } & -0.1917 & 0.0559 & 11.74 & 0.00061 \\ \beta_{0} & 0.0134 & 0.2767 & 0.00 & 0.96132\end{array}$

$\dagger$ Models: $m i_{\mathrm{d}}$, models adjusted using distance variables; $\mathrm{m} i_{\mathrm{ej}}$, models adjusted using neighborhood variables by scale; $m i_{\mathrm{dej}}$, models adjusted using distance and neighborhood variables; $m i_{\mathrm{dej}} / k$, models adjusted using distance and neighborhood variables with combined scales; $i$ is the model number and $j$ and $k$ are scale identifiers, with $j$ and $k=150,300,600,900$, or $1200 \mathrm{~m}$.

$\$$ Akaike information criterion.

$\S$ Nagelkerke's $R^{2}$.

urban growth. These variables remained negative; thus, the closer were access roads and highways, the more probable was urban growth. Urban growth was also significantly related to the two environmental variables of elevation and soil type, and significantly positively related to the density of the urban road network within the 300-m neighborhood and density of urban areas within the 300-m neighborhood (Table 3C).

Again, the models based on the 500-m urban growth surface were much poorer than those based on 3000$m$ urban growth surface. The integration of distance and neighborhood variables, however, improved the global fit, and the model with 150-m neighborhood variables provided the best fit (Table 4C).

\section{Models with mixed scales}

For the 3000-m urban growth surface, a mixed model, $\mathrm{m} 12_{\text {de } 10 / 40}$, that incorporated neighborhood density variables at two different scales was generated from the two models with the best global fit, i.e., $\mathrm{m} 8_{\text {de } 10}$ and $\mathrm{m} 11_{\text {de } 40 .}$. Using this new model, the AIC decreased significantly to 283.9 and Nagelkerke's $R^{2}$ increased to 0.74 . Nevertheless, despite a noticeable improvement in the model's global fit, the variables of distance from access roads, distance from highways, and density of the urban roadway network continued to be the best predictors of urban growth. In the case of the density of the urban roadway network, the 1200-m neighborhood gave the best results (Table 3D). This model shows that elements such as the general urban area and industrial areas can have opposite effects at different spatial scales. The density of urbanized cells within a 300 -m radius had a significant positive effect on the probability of urbanization, whereas the density of industrial areas within a 1200-m radius had a significant negative effect.

For the 500-m urban growth surface, we obtained a mixed model that greatly improved the model fit. However, the fit was still poor compared to the model based on the 3000-m urban growth surface. With these new models, e.g., $\mathrm{m} 12_{\mathrm{de} 10 / 40}$, the AIC decreased to 545.5 and Nagelkerke's $R^{2}$ increased to 0.3031 . Despite noticeable improvement in the model's global fit, the density of the urban road network continued to be the best predictor of urban growth (Table 4D).

\section{Urban growth prediction for 1992-1998 using models based on a 3000-m growth surface}

By comparing the predicted results with the observed urban land cover change between 1992 and 1998, the transition matrices (Table 5A) showed the classification error for the three models with best global fit: $\mathrm{m} 8_{\mathrm{de} 10}, \mathrm{~m} 11_{\mathrm{de} 40}$, and $\mathrm{m} 12_{\mathrm{de} 10 / 40}$. Model $\mathrm{m} 11_{\text {de } 40}$ gives minor classification error with $8.5 \%$ of cells classified incorrectly $(25,552$ of 299,730 cells). Nevertheless, model $\mathrm{m} 8_{\text {de10 }}$ gives the best classification for cells with urban growth, with $72.3 \%$ of cells classified correctly (3677 of 5087 cells). 
Table 5. Transition matrices evaluating the predictions of the best models using the (A) 3000-m and (B) 500-m growth surface by the number of cells correctly classified as having growth or no growth in urban area. Correctly classified cells are in boldface, incorrecly classified cells are in normal type, and numbers in parentheses indicate percentage of cells.

\begin{tabular}{|c|c|c|c|c|c|c|c|c|c|c|c|c|}
\hline & \multicolumn{4}{|c|}{$\mathrm{m} 8_{\mathrm{de} 10}$} & \multicolumn{4}{|c|}{$\mathrm{m} 11_{\mathrm{de} 40}$} & \multicolumn{4}{|c|}{$\mathrm{m} 12_{\mathrm{de} 10 / 40}$} \\
\hline & & No growth & Growth & Total & & No growth & Growth & Total & & No growth & Growth & Total \\
\hline \multirow{3}{*}{$\begin{array}{l}\text { Urban a- } \\
\text { rea in } \\
1998\end{array}$} & No growth & $\begin{array}{c}264,099 \\
(89.6)\end{array}$ & $\begin{array}{c}30,544 \\
(10.4)\end{array}$ & $\begin{array}{c}294,643 \\
(100)\end{array}$ & No growth & $\begin{array}{c}271,220 \\
(92.1)\end{array}$ & $\begin{array}{c}23,423 \\
(7.9)\end{array}$ & $\begin{array}{c}294,643 \\
(100)\end{array}$ & No growth & $\begin{array}{c}270,081 \\
(91.7)\end{array}$ & $\begin{array}{c}24,562 \\
(8.3)\end{array}$ & $\begin{array}{c}294,643 \\
(100)\end{array}$ \\
\hline & Growth & $\begin{array}{l}1410 \\
(27.7)\end{array}$ & $\begin{array}{l}3677 \\
(72.3)\end{array}$ & $\begin{array}{l}5087 \\
(100)\end{array}$ & Growth & $\begin{array}{c}2129 \\
(41.8)\end{array}$ & $\begin{array}{c}2958 \\
(58.2)\end{array}$ & $\begin{array}{l}5087 \\
(100)\end{array}$ & Growth & $\begin{array}{l}1831 \\
(36)\end{array}$ & $\begin{array}{l}3256 \\
(64)\end{array}$ & $\begin{array}{l}5087 \\
(100)\end{array}$ \\
\hline & Total & 265,509 & 34,221 & 299,730 & Total & 273,349 & 26,381 & 299,730 & Total & 271,912 & 27,818 & 299,730 \\
\hline
\end{tabular}

(B)

\begin{tabular}{|c|c|c|c|c|c|c|c|c|c|c|c|c|}
\hline & \multicolumn{4}{|c|}{$\mathrm{m} 7_{\mathrm{de} 5}$} & \multicolumn{4}{|c|}{$\mathrm{m} 8_{\mathrm{de} 10}$} & \multicolumn{4}{|c|}{$\mathrm{m} 12_{\mathrm{de} 10 / 40}$} \\
\hline & & No growth & Growth & Total & & No growth & Growth & Total & & No growth & Growth & Total \\
\hline \multirow{3}{*}{$\begin{array}{l}\text { Urban a- } \\
\text { rea in } \\
1998\end{array}$} & No growth & $\begin{array}{c}273,746 \\
(92.9)\end{array}$ & $\begin{array}{c}20,897 \\
(7.1)\end{array}$ & $\begin{array}{c}294,643 \\
(100)\end{array}$ & No growth & $\begin{array}{c}262,648 \\
(89.1)\end{array}$ & $\begin{array}{c}31,995 \\
(10.9)\end{array}$ & $\begin{array}{c}294,643 \\
(100)\end{array}$ & No growth & $\begin{array}{c}263,353 \\
(89.4)\end{array}$ & $\begin{array}{c}31,290 \\
(10.6)\end{array}$ & $\begin{array}{c}294,643 \\
(100)\end{array}$ \\
\hline & Growth & $\begin{array}{c}2467 \\
(48.5)\end{array}$ & $\begin{array}{c}2620 \\
(51.5)\end{array}$ & $\begin{array}{l}5087 \\
(100)\end{array}$ & Growth & $\begin{array}{l}1882 \\
(37)\end{array}$ & $\begin{array}{c}3205 \\
(63)\end{array}$ & $\begin{array}{l}5087 \\
(100)\end{array}$ & Growth & $\begin{array}{c}2229 \\
(43.8)\end{array}$ & $\begin{array}{c}2858 \\
(56.2)\end{array}$ & $\begin{array}{l}5087 \\
(100)\end{array}$ \\
\hline & Total & 276,213 & 23,517 & 299,730 & Total & 264,530 & 35,200 & 299,730 & Total & 265,582 & 34,148 & 299,730 \\
\hline
\end{tabular}

Note: These data allow the calculation of the total percentage of correctly classified cells. For example, according to model $\mathrm{m} 8_{\mathrm{de} 10}$ for the 3000-m growth surface, of the total of 299,730 cells, 264,099 cells and 3677 cells were correctly predicted to have no growth and growth, respectively, yielding a total of $89.3 \%$ of all cells that were correctly predicted by this model.

The explicit spatial model predictions for 1998 using the parameters of the above three models constructed for the 1978-1992 period and the variables generated for 1992 were illustrated (Fig. $4 \mathrm{~A}-\mathrm{C})$. Although the three models varied in some details, they produced overall consistent predictions. First, the area east of the city shows a high probability of urban growth due to the proximity to access roads and highway. Second, there is a high probability of urban growth in the immediate neighborhood of the city. Finally, all three models predicted a high probability of growth for the traffic nodes in the south because of the proximity to access roads and highways.

Most of the areas incorrectly classified as areas of urban growth were located in the immediate neighborhood of the 1992 city or close to access roads and highways (Fig. 4A-C). The models produced a rather smooth, diffusion-like probability 
Fig. 4. Model predictions for urban growth in 1998 giving the probability of growth for each cell. (A) Model $\mathrm{m} 8_{\mathrm{de} 10}$, (B) model $\mathrm{m} 11_{\mathrm{de} 40}$, and (C) model $\mathrm{m} 12_{\mathrm{de} 10 / 40}$, based on the $3000-\mathrm{m}$ growth surface. (D) Model $\mathrm{m} 7_{\mathrm{de} 5}$, (E) model $\mathrm{m} 8_{\mathrm{de} 10}$, and $(\mathrm{F})$ model $\mathrm{m} 12_{\mathrm{de} 10 / 40}$, based on the 500 - $\mathrm{m}$ growth surface.

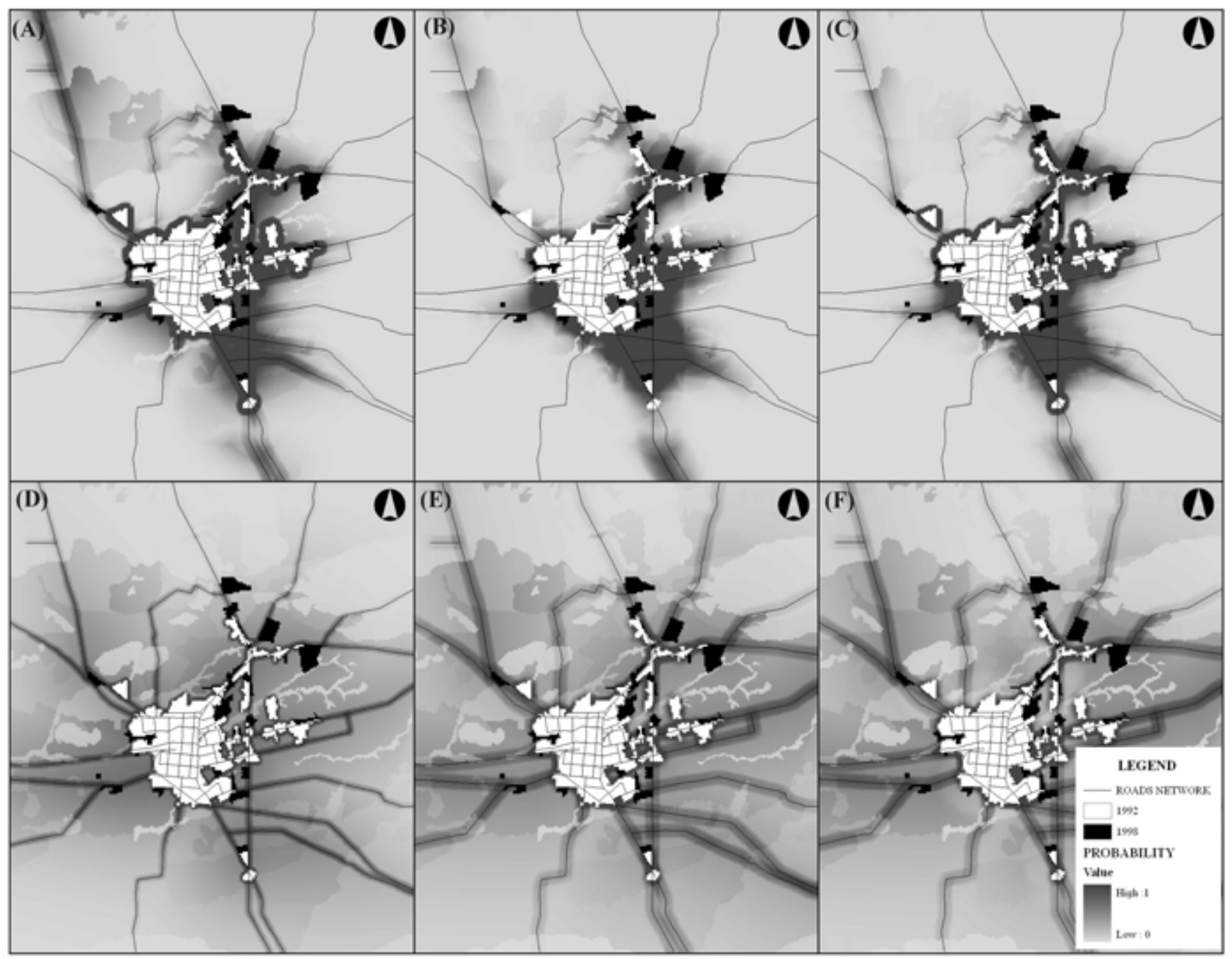

of growth. However, actual growth proceeded in somewhat larger blocks (Fig. 2A), mostly in areas with a high predicted probability of growth.

\section{Urban growth prediction for 1992-1998 using models based on a 500-m growth surface}

The models using the 500-m growth surface were much poorer than those using the 3000-m growth surface, especially in the predictions of cells with urban growth. The models gave high weight to streets and highways (Fig. 4D-F). The transition matrices (Table 5B) showed the classification error for the three models with best global fit: $\mathrm{m} 7_{\mathrm{de} 5}$, $\mathrm{m} 8_{\mathrm{de} 10}$, and $\mathrm{m} 12_{\mathrm{de} 10 / 40}$. Model $\mathrm{m} 7_{\mathrm{de} 5}$ gave minor classification error with $8.7 \%$ of cells classified incorrectly. Nevertheless, model $\mathrm{m}_{\mathrm{de} 10}$ gave the best classification for cells with urban growth, with a classification error of $37 \%$ (3205 of 5087 cells). 


\section{DISCUSSION}

\section{Mechanisms of urban growth in Los Ángeles}

Our results show that the urban growth of mid-cities can be successfully described by variables related to accessibility and the neighborhood density of urban elements at different spatial scales. The validation of the statistical models constructed using data from the 1978-1992 period and validated for the 1992-1998 period showed that some $90 \%$ of all observed land cover transitions were correctly predicted by the best models. This relatively high classification accuracy is comparable to that of the logistic models of Allen and Lu (2003). We identified three major factors influencing urban growth in Los Ángeles: accessibility, diffusion growth in the immediate neighborhood of the city, and traffic nodes.

\section{Accessibility}

All of the models analyzed were consistent in confirming the heavy dependence of Los Ángeles's urban growth on variables related to accessibility, quantifying its force and direction. There was indeed substantial growth in the area east of the 1992 city related to the proximity of road infrastructure (Fig. 4A-C). The relationship established between urban growth and the distance from highways and access roads, for example, follows the typical distance decay function in which the probability of land-use change decreases with increased distance. However, we also found a significant effect of the density of the urban road network at the local scale up to $1200 \mathrm{~m}$, which suggests that not only largescale accessibility because of highways and access roads is important, but also small-scale accessibility because of a dense local urban road network.

The distance from rural roads was not considered in the logistic regression. This was because the frequency of cells with urban growth was not associated with specific distance ranges regarding these elements, and, consequently, growth was not significantly different than random. This is consistent with our analysis because the majority of rural roads do not offer good accessibility to centers of consumption and services, which are mostly located in the downtown area.
Diffusion growth in close proximity to the existing city

The occurrence of a large part of urban growth adjacent to already established and consolidated urban areas was also observed and quantified by variables describing the density of urban area in the local neighborhood of 300-600 m because these new urban areas can easily be connected to the existing roadway network. Consequently, the inhabitants can easily access all the required goods and benefit from all the previously established services. Indeed, most of the observed growth occurred as diffusion growth extending from the already existing urban areas in a gap-filling manner. An example is a large gap located at the middle west of the 1992 city that was completely filled 1998 (Fig. 2A).

In Los Ángeles, as in other mid-cities of central Chile such as Chillán, Temuco, Valdivia, and Puerto Montt, most important township, provincial, and regional urban services and amenities are located in or near the city's historic downtown. Clearly, these areas weigh heavily on the type of growth experienced and resulting patterns of land use. Therefore, their connectivity or accessibility assures the provision of urban services and amenities for the population. However, the differentiated behavior of the roadway network on urban growth should be pointed out because certain types of roads promote changes in land use and associated activities. In most of our models, access roads to the city best explained the probability of land-use changes. The city's structuring roadways, i.e., the roads that directly connect the historic downtown to the main access roads into urban and adjacent rural areas, are particularly relevant. This type of road largely explains urban growth by the aggregation of areas to the existing urban tract.

\section{Traffic nodes}

Urban growth occurring farther from the city's downtown area is found adjacent to main access roads in areas that constitute communication and transportation nodes that are especially apt for industrial activities, the storage of goods, and the transformation of raw materials originating from rural sectors of the township and the Biobío Province. This location is geographically ideal, with 
access to markets of consumption and urban work, as well as services and amenities. Furthermore, the location of industries around these nodes is also advantageous because the nodes offer access to the region's main ports, especially in the case of forestry production, and other similar urban centers such as Chillán and Temuco.

\section{Environmental variables}

Natural elements such as rivers and topographic conditions do not greatly interfere with the city's growth and structuring process. In other words, natural elements do not act as thresholds, nor are they driving forces of Los Ángeles's urban growth. In fact, most rivers that cross Los Ángeles have been artificially channeled and rerouted from their natural trajectories. This finding is in contrast to those of other studies (e.g., Brown et al. 2002, Pijanowski et al. 2002) that have found that access to water bodies such as lakes and rivers or aesthetic values such as the quality of the view influence growth trajectories. However, water bodies in Los Ângeles are rather minor landscape elements compared to the dominating Lake Michigan in the study by Pijanowski et al. (2002). Of the modeled environmental variables, the soil type was significant in all adjusted models, mainly because of the predominance of certain soil types in which the greatest frequencies of land-use change occurred. Nearly half of the recent changes in land use took place on flat and deep soils that are well drained and pose no limit to agricultural applications. This indicates that urban growth in Los Angeles, as in most Chilean cities, is taking place on the most productive agricultural tracts (CONAMA-CONAF-BIRF 1999). This is highly relevant considering that nearly one-quarter of the terrain planned or normalized in local urban planning instruments is projected on areas apt for agricultural use (Soto and Ulloa 1997, Henríquez et al. 2006, Azócar et al. 2007). In other words, it seems apparent that the rural areas bordering the outer urban limits, or even those farther from the city, are subjected or submitted to the pressures of real estate and industrial development and that, in fact, they are not only perceived in terms of their agricultural productivity, but also in terms of the future land rent that urban activities could yield compared to their present agricultural activities.

\section{Further growth of Los Ángeles}

Both the density of the roadway networks and previously established urban areas explain a good portion of urban growth. Future growth is more likely in areas adjacent to already consolidated urban sectors that have good accessibility and connectivity, especially in relation to the services and amenities located in the more central areas. This is relevant for residential urban activities, specifically public housing projects developed under public policies for low-income and middleclass sectors. However, middle- and high-income groups are requiring urban land that is ever farther away from downtown, on the periphery of or in contact with rural areas. In effect, some models, e. g., $\mathrm{m} 12_{\text {de10/40 }}$ or $\mathrm{m} 11_{\text {de } 40}$, include the density of industrial areas as a disincentive for urban growth for specific uses, mainly residential. Therefore, real estate projects are less likely to develop close to areas presently used for industry.

\section{Noncontinuous growth}

Most of the cells incorrectly classified as urban growth were located in the immediate neighborhood of the 1992 city or close to access roads and highways (Fig. 4A-C). This points to a mechanism driving the urban growth of Los Ángeles that is not well accounted for by our models. Growth does not work as small-scale, cellwise diffusion, as suggested by the smooth probability surface of our models, but rather appears as a stochastic process in which larger blocks are urbanized in areas classified by the model as highly susceptible for growth. This is probably related to the particular method of urbanization in which houses are not constructed individually by individual owners, but rather as large multihouse developments on blocks of land of a certain minimal size. In this context, the decision to urbanize or not to urbanize may also be related to the size of a property or other factors such as urban planning, which were not included in our models. However, our models clearly depict the areas highly susceptible to urban growth. If we waited long enough, we suspect that all highly susceptible remaining gaps would eventually be filled.

This result suggests that subsequent modeling should consider the stochastic blockwise character of the observed urban growth. One possibility for this is to extend the present models to simple, rulebased, stochastic cellular models (e.g., Allen and Lu 2003 ) in which blocks of nonurbanized $30 \times 30 \mathrm{~m}$ cells are defined based on criteria such as property size, and the logistic model is used to assign each block a probability of change. Random draws then 
decide in a stochastic manner whether the block will be urbanized in the next time step.

\section{The issue of spatial scales}

Compared to other recent models in which expanded logistic regression methods were used to analyze the urbanization process (e.g., Brown et al. 2002, Allen and Lu 2003) we decided to use logistic regression in our initial modelling step, but to place special emphasis on deriving appropriate predictive variables and on the issue of scale. Urbanization is certainly a multiscale process. For example, the attractiveness of a new middle-class urban development may be reduced if there are many industrial areas within a distance of 1 or $2 \mathrm{~km}$, but it may be enhanced if there is a high density of urban roads within a distance of several hundred meters. Distance variables cannot account for critical spatial scales related to the presence of certain elements such as roads or urbanized areas. Instead, this requires the construction of neighborhood variables that indicate the density of these elements at different spatial scales.

To study the influence of the different types of variable we constructed a sequence of models starting with more traditional models containing only distance variables and environmental variables. We then included neighbourhood variables at different spatial scales in subsequent steps. This exercise clearly demonstrated that both traditional distance variables and neighborhood density variables at various spatial scales are required to appropriately capture the multiscale urban growth process.

We also investigated the impact of spatial scale on the construction of the dependent variable. The logistic model constructed using the 3000-m growth surface predicted a high probability of growth in the immediate neighborhood of the city, with little power to discriminate the blocks of land that were actually urbanized from those that were not urbanized but had a high probability of becoming urbanized (Fig. 4A-C). Initially, we attributed this shortcoming of the model to the fact that we sampled the areas of no growth from a relatively wide area around the city's perimeter, thus having relatively few data points from locations in the immediate neighborhood of the city (Fig. 3D) with which to discriminate more subtle effects. We therefore repeated the analyses using a smaller growth surface of $500 \mathrm{~m}$ from the city's perimeter (Fig. 3D) in the hope of finding some variables that would be able to depict a higher probability for blocks of cells in the immediate neighborhood of the city that showed growth. However, analyses of models using the 500$\mathrm{m}$ growth surface did not yield any improvement, but in fact, produced much poorer models. This is a valuable lesson that outlines the importance of selecting the appropriate numbers of cells with a value of 0 for the response variable.

The reason for the failure of the models constructed using the $500-\mathrm{m}$ growth surface might be that the data points selected to be representative of no growth were not really representative and missed important combinations of variables, thus providing a poor training data set. In other words, our results show that the probability of urbanization in Los Ángeles is not only determined by the conditions in the immediate 500-m neighborhood of the city, but must also be put into perspective with regard to the conditions of more distant locations.

The lack of model improvement using the 500-m growth surface indicates that, whereas the 3000-m model clearly points to areas of high susceptibility for urbanization, the actual urbanization process likely proceeds in a stochastic blockwise manner, as described above. Whether this process is really stochastic or is driven by factors not quantified by the variables included in our models, such as the shape of rural properties, urban planning, and land prices, will be the subject of forthcoming studies and modeling efforts. In any case, our models contributed to identifying this question.

\section{Subsequent modeling steps}

An important challenge for future modeling efforts is to understand the observed blockwise growth pattern in which houses are not constructed individually, but rather as larger multihouse developments. Our models did not consider factors related to this growth pattern. However, our findings clearly depict the areas susceptible to this type of urban growth.

It is also necessary to identify the variables and factors that allow the construction of predictive models that are able to provide more detailed information regarding the urban growth dynamic in residential and industrial areas and, especially, the role of some local factors in growth processes. One 
such challenge will be the construction of models that can discriminate among the growth of industrial, commercial, and residential areas and, in the latter case, among neighborhoods according to their social groups and income levels. Such models would allow an understanding of the differences and similarities among different urban downtown areas of similar or different ranges and hierarchies. It will also be necessary to incorporate the temporal dimension into the modeling to analyze the dynamic with which the changes in use occur along a defined time line. These analytical approaches and techniques can contribute significantly to defining future scenarios of urban development and identifying the causal factors or driving forces of growth or decline in a city or group of cities, as well as visualizing tendencies in land use and the corresponding economic, social, and environmental effects.

\section{Application of our approach}

Logistic regression is basically a nonspatial modeling technique. We therefore placed special emphasis on issues of space and critical spatial scales. Our approach to this was grounded in studies of the habitat selection of large carnivores (Schadt et al. 2002, Naves et al. 2003) and is thus not limited to studies of urban growth or to the particularities of the selected city of Los Ángeles, Chile. Critical steps in the application of our approach to other regions in and outside of Chile are (1) the selection of variables that represent well defined hypothesis of urban growth in the particular study area and the construction of scale-dependent neighborhood density variables at appropriate scales; (2) the use of a variable reduction approach that groups all possible models arising from different scales and types of variables into blocks; (3) the use of alternative growth surfaces to find the appropriate scale for the selection of cells with a value of 0 of the dependent variable; and (4) the mitigation of spatial autocorrelation in the construction of the dependent variable.

Our approach is appealing in its simplicity and power; other models that provide similarly accurate results are hybrid models (e.g., White and Engelen 2000, Allen and Lu 2003), and the small spatial scale makes it useful not simply in the field of conservation, but also in urban planning. Although it has long been known that access to roads drives the development of urban growth in Chile and that flat topography and well-drained soil are preferred for urbanization (e.g., Mumford 1951), new insight and understanding is provided by our approach, which is able to identify critical scales in driving variables, e.g., the density of industrial areas or the urban roadway network within a 1200-m neighborhood or the density of urbanized cells within a 300-m neighborhood. Such understanding could be used to identify factors that tend to favor growth close to the urban core, thereby mitigating sprawling suburban expansion. An example of this is the diffusion growth that occurs in close proximity to existing urbanized areas.

\section{CONCLUSIONS}

Our results show that the urban growth of mid-cities can be successfully described by variables related to the accessibility and neighborhood density of urban elements at different spatial scales. In effect, all the models analyzed confirmed the dependence of Los Ángeles's urban growth on variables related to accessibility. Nevertheless, not only distances variables proved to be important for modeling the spatial growth patterns, but also scale-dependent density variables. Urbanization is a multiscale process, and distance variables alone cannot properly account for spatial scales in the density of certain elements such as roads or urbanized areas. Clearly, it is not a novel finding that variables related to accessibility explain urban growth; however, our approach was able to identify critical scales at which these variables operate, providing new insight and understanding. This is useful information for planners to control or decrease the potential impacts of urban sprawl.

Urban growth often occurred as diffusion growth extending from already existing urban areas in a gap-filling manner. Our results suggest that an important part of the city's future growth may occur in areas adjacent to already consolidated urban sectors, thereby mitigating sprawling suburban expansion. The driving variables of this type of growth are good accessibility and connectivity, especially in relation to the services and amenities located in the more central areas.

The current urban growth of Los Ángeles shows that the urban planning policies have been largely overcome by private interests beyond the planned urban area. As a consequence, city sprawl has occurred partly in a diffuse manner. This, along with 
other effects, has caused the increasing socio-spatial segregation of the population and the permanent modification of urban planning instruments. For example, middle- to high-class neighborhoods appear on the urban periphery and benefit from good accessibility, green areas, and spatial attributes that highlight the economic condition of the occupants. In contrast, low-income neighborhoods are often found in areas with poor accessibility, low esthetic value, e.g., few green areas, and in areas with spatial disadvantages, e.g., near landfills or flood areas. Although local authorities are aware of the unsustainable nature of the growth dynamic, they have limited tools and resources to generate strategies that reverse the observed tendencies.

To understand the city's current and future growth patterns and to identify the factors that influence it can be very important for generating sustainable urban development strategies. Appropriate land-use planning in rapidly growing mid-sized cities requires normative support that is expressed in the compliance with and respect for urban development policies. While effective congruence between the political will to develop a harmonious city and the concrete events carried out by public and private persons is lacking, all efforts will be futile. Because these mid-cities are still managed on a human scale, urgent measures are justified to prevent repeating the errors made in the development of large cities.

Responses to this article can be read online at: http://www.ecologyandsociety.org/vol12/iss1/art13/responses/

\section{Acknowledgments:}

This work was developed as part of the International Cooperation Project CONICYT-BMBF 2003-4-134 and FONDECYT 1050423, which allowed all authors to travel for cooperative work.

\section{LITERATURE CITED}

Alig, R. J. 1986. Econometric analysis of the factors influencing forest acreage trends in the southeast. Forest Science 32:119-134.

Allen, J., and K. Lu. 2003. Modeling and prediction of future urban growth in the Charleston region of South Carolina: a GIS-based integrated approach. Conservation Ecology 8:2. [online] URL: http://www.consecol.org/vol8/iss2/art2.

Azócar, G., H. Romero, R. Sanhueza, C. Vega, M. Aguayo, and M. D. Muñoz. 2007. Urbanization patterns and their impacts on social restructuring of urban space in Chilean mid-cities: the case of Los Ángeles, central Chile. Land Use Policy 24:199-211.

Azócar, G., R. Sanhueza, and C. Henríquez. 2003. Análisis del cambio en los patrones de crecimiento urbano en una ciudad intermedia de Chile central: un caso de estudio en Chillán. EURE (Santiago) 29(87):79-82.

Bella, K. P., and E. G. Irwin. 2002. Spatially explicit micro-level modelling of land use change at the rural-urban interface. Agricultural Economics 27:217-232.

Bellet Sanfeliu, C., and J. M. Llop Torné. 2004. Miradas a otros espacios urbanos: las ciudades intermedias. Geo Crítica / Scripta Nova. Revista Electrónica de Geografía y Ciencias Sociales 8:165. [online] URL: http://www.ub.es/geocrit/sn/ sn-165.htm\# ftn1.

Berling-Wolff, S., and J. Wu. 2004a. Modeling urban landscape dynamics: a case study in Phoenix, USA. Urban Ecosystems 7:215-240.

Berling-Wolff, S., and J. Wu. 2004b. Modeling urban landscape dynamics: a review. Ecological Research 19:119-129.

Bockstael, N. E. 1996. Modeling economics and ecology: the importance of a spatial perspective. American Journal of Agricultural Economics $\mathbf{7 8}$ (5):1168-1180.

Borsdorf, A. 2000. El desarrollo urbano de Valdivia. Estudio de caso en una ciudad mediana chilena. Revista Espacio y Desarrollo 12:45-82.

Breuste, J., H. Feldmann, and O. Uhlmann, editors. 1998. Urban ecology. Springer-Verlag, Berlin, Germany.

Brown, D. G., P. Goovaerts, A. Burnicki, and M.Y. Li. 2002. Stochastic simulation of land-cover change using geostatistics and generalized additive models. Photogrammetric Engineering and Remote 
Sensing 68(10):1051-1062.

Burnham, K.P., and D. R.Anderson. 1998. Model selection and inference: a practical informationtheoretic approach. Springer-Verlag, New York, New York, USA.

Corporación Nacional Forestal-Comisión Nacional del Medio Ambiente-Banco Interamericano de Reconstrucción y Fomento (CONAMA-CONAFBIRF). 1999. Catastro y evaluación de los recursos vegetacionales nativos de Chile. Informe Regional, Octava Región. CONAF-CONAMA, Santiago, Chile.

de Koning, G. H. J., P. H. Verburg, A. Veldkamp, and L. O. Fresco. 1999. Multi-scale modelling of land use change dynamics in Ecuador. Agricultural Systems 61:77-93.

Foresman, T. W., S. T. A. Pickett, and W. C. Zipperer. 1997. Methods for spatial and temporal land use and land cover assessment for urban ecosystems and application in the greater Baltimore-Chesapeake region. Urban Ecosystems 1:201-216.

Glaeser, E. L. 1998. Are cities dying? Journal of Economic Perspectives 12:139-160.

González, M. 1994. La fragilidad del medio natural en la expansión urbana de ciudades de rango medio. Algunos alcances para tres ciudades chilenas: Curicó, Talca y Linares. Revista Geográfica de Chile Terra Australis 39:103-109.

Gordon, P., and H. W. Richardson. 1997. Are compact cities a desirable planning goal? Journal of the American Planning Association $\mathbf{6 3}$ (1):95-106.

Henríquez, C., G. Azócar, and H. Romero. 2006. Monitoring and modeling the urban growth of two mid-sized Chilean cities. Habitat International 30:945-964.

Herbert, D. T., and C. J. Thomas. 1982. Urban geography: a first approach. Wiley, New York, New York, USA.

Hylton, T. 1995. Save our land, save our towns: a plan for Pennsylvania. RB Books, Harrisburg, Pennsylvania, USA.
Johnson, J. B., and K. S. Omland. 2004. Model selection in ecology and evolution. Trends in Ecology and Evolution 19:101-108.

LaGro, J. A., and S. D. DeGloria. 1992. Land use dynamics within an urbanizing non-metropolitan county in New York State (USA). Landscape Ecology 7:275-289.

López, E., G. Bocco, M. Mendoza, and E. Duhau. 2001. Predicting land-cover and land-use change in the urban fringe: a case in Morelia city, Mexico. Landscape and Urban Planning 55:271-285.

Marsh, W. M. 1991. Landscape planning, environmental applications. Second edition. Wiley, New York, New York, USA.

McDonnell M. J., and S. T. A. Pickett. 1993. Humans as components of ecosystems: the ecology of subtle human effects and populated areas. Springer-Verlag, New York, New York, USA.

Mumford, L. 1951. The conduct of life. Harcourt Brace, New York, New York, USA.

Naves, J., T. Wiegand, E. Revilla, and M. Delibes. 2003. Endangered species constrained by natural and human factors: the case of brown bears in northern Spain. Conservation Biology 17:1276-1289.

Newman, P., J. Kenworthy, and P. Vintila. 1992. Housing, transport and urban form. National Housing Strategy, Department of Health, Housing and Community Services, Canberra, Australia.

Parker, R. A. 1995. Patterns of federal urban spending: central cities and their suburbs, 19831992. Urban Affairs Review 31(2):184-205.

Pauchard, A., M. Aguayo, E. Peña, and R. Urrutia. 2006. Multiple effects of urbanization on the biodiversity of developing countries: the case of a fast-growing metropolitan area (Concepción, Chile). Biological Conservation 127:272-281.

Pickett, S. T. A., W. R. Burch, S. E. Dalton, T. W. Foresman, J. M. Grove, and R. Rowntree. 1997. A conceptual framework for the study of human ecosystems in urban areas. Urban Ecosystems 1:185-199.

Pickett, S. T. A., and M. L. Cadenasso. 1995. Landscape ecology: spatial heterogeneity in 
ecological systems. Science 269:331-334.

Pickett, S. T. A., M. L. Cadenasso, J. M. Grove, C. H. Nilon, R. V. Pouyat, W. C. Zipperer, and R. Costanza. 2001. Urban ecological systems: linking terrestrial ecological, physical, and socioeconomic components of metropolitan areas. Annual Review of Ecology and Systematics 32:127-157.

Pijanowski, B. C., D. G. Brown, B. A. Shellito, and G. A. Manik. 2002. Using neural networks and GIS to forecast land use changes: a Land Transformation Model. Computers, Environment, and Urban Systems 26:553-575.

Qi, Y., and J. Wu. 1996. Effects of changing spatial resolution on the results of landscape pattern analysis using spatial autocorrelation indices. Landscape Ecology 11(1):39-49.

Rodríguez, J., and M. Villa. 1998. Distribución espacial de la población, urbanización y ciudades intermedias: hechos en su contexto. Pages 25-68 in R. Jordan and D. Simioni, editors. Ciudades intermedias de América Latina y el Caribe: propuestas para la gestión urbana. Comisión Económica para América Latina y el Caribe (CEPAL). [online] URL: http://www.eclac.cl/publi caciones/MedioAmbiente/7/lcl1117/lc11117.pdf.

Romero, H., and X. Toledo. 2000. Ecología urbana y sustentabilidad ambiental de las ciudades intermedias chilenas. Anales de la Sociedad Chilena de Ciencias Geográficas 2000:445-452.

Rovira Pinto, A. 2000. Puerto Montt: el paso de una ciudad menor a centro de desarrollo interregional en una ciudad del sur de Chile. Espacio y Desarrollo 12:83-102.

Sabatini, F. 1998. Direcciones para el futuro. Pages 127-214 in R. Jordan and D. Simioni, editors. Ciudades intermedias de América Latina y el Caribe: propuestas para la gestión urbana. Comisión Económica para América Latina y el Caribe (CEPAL). [online] URL: http://www.eclac. cl/publicaciones/MedioAmbiente/7/lcl1117/lc11117. pdf.

Schadt, S., E. Revilla, T. Wiegand, F. Knauer, P. Kaczensky, U. Breitenmoser, L. Bufka, J. Cervený, P. Koubek, T. Huber, C. Stanisa, and L. Trepl. 2002. Assessing the suitability of central European landscapes for the reintroduction of
Eurasian lynx. Journal of Applied Ecology 39:189-203.

Shtatland, E.S., E. Cain, and M. B. Barton. 2001. The perils of stepwise logistic regression and how to escape them using information criteria and the Output Delivery System. Pages 222-226 in Proceedings of the 26th Annual SAS Users Group International Conference. SAS Institute, Cary, North Carolina, USA.

Soto, G., and F. Ulloa. 1997. Diagnóstico de la desertificación en Chile. Corporación Nacional Forestal (CONAF), La Serena, Chile.

Theobald, D. M., and N. T. Hobbs. 1998. Forecasting rural land-use change: a comparison of regression- and spatial transition-based models. Geographical and Environmental Modelling 2 (1):65-82.

Theobald, D. M., J. M. Miller, and N. T. Hobbs. 1997. Estimating the cumulative effects of development on wildlife habitat. Landscape and Urban Planning 39:25-36.

White, R., and G. Engelen. 2000. High-resolution integrated modelling of the spatial dynamics of urban and regional systems. Computers, Environment and Urban Systems 24:383-400.

Wiegand, T., W. D. Kissling, P. A. Cipriotti, and M. R. Aguiar. 2006. Extending point pattern analysis for objects of finite size and irregular shape. Journal of Ecology 94:825-837.

Wu, F. 1998. Simulating urban encroachment on rural land with fuzzy-logic-controlled cellular automata in a geographical information system. Journal of Environmental Management 53:293-308.

Zhou, G., and A. M. Liebhold. 1995. Forecasting the spatial dynamics of gypsy moth outbreaks using cellular transition models. Landscape Ecology 10: $177-189$. 